\title{
Renin Activity in Heart Failure with Reduced Systolic Function-New Insights
}

\author{
Ryan D. Sullivan, Radhika M. Mehta ${ }^{\dagger}$, Ranjana Tripathi $^{\dagger}{ }^{\dagger}$, Guy L. Reed ${ }^{*}$ \\ and Inna P. Gladysheva *D \\ Department of Internal Medicine, University of Arizona College of Medicine-Phoenix, Phoenix, AZ 85004, USA \\ * Correspondence: guyreed@email.arizona.edu (G.L.R.); innagladysheva@email.arizona.edu (I.P.G.); \\ Tel.: +602-827-2919 (I.P.G.); Fax: +602-827-2068 (I.P.G.) \\ + Authors contributed equally.
}

Received: 16 May 2019; Accepted: 27 June 2019; Published: 28 June 2019

\begin{abstract}
Regardless of the cause, symptomatic heart failure (HF) with reduced ejection fraction $(\mathrm{rEF})$ is characterized by pathological activation of the renin-angiotensin-aldosterone system (RAAS) with sodium retention and extracellular fluid expansion (edema). Here, we review the role of active renin, a crucial, upstream enzymatic regulator of the RAAS, as a prognostic and diagnostic plasma biomarker of heart failure with reduced ejection fraction (HFrEF) progression; we also discuss its potential as a pharmacological bio-target in HF therapy. Clinical and experimental studies indicate that plasma renin activity is elevated with symptomatic HFrEF with edema in patients, as well as in companion animals and experimental models of HF. Plasma renin activity levels are also reported to be elevated in patients and animals with rEF before the development of symptomatic HF. Modulation of renin activity in experimental HF significantly reduces edema formation and the progression of systolic dysfunction and improves survival. Thus, specific assessment and targeting of elevated renin activity may enhance diagnostic and therapeutic precision to improve outcomes in appropriate patients with HFrEF.
\end{abstract}

Keywords: heart failure; plasma renin activity; renin-angiotensin-aldosterone system; renin; prorenin; (pro)renin receptor; reduced systolic function; dilated cardiomyopathy; direct renin inhibitor; aldosterone

\section{Introduction}

Symptomatic heart failure (HF) with reduced ejection fraction (rEF) affects millions and is the most common reason for heart transplantation [1-3]. The prevalence of symptomatic HF will increase $46 \%$ from 2012 to 2030 [4]. Dilated cardiomyopathy (DCM) due to nonischemic or ischemic causes is characterized by progressive heart enlargement with $\mathrm{rEF}$, which is a major risk factor for the development of symptomatic heart failure with reduced ejection fraction (HFrEF) $[2,3,5,6]$.

The American College of Cardiology/American Heart Association (ACC/AHA) staging system suggests that HFrEF predictably progresses though four stages, from A to D. Patients at risk for DCM have Stage A HF and usually progress to Stage B, where there is a decline in systolic function; both Stages A and B are without symptoms or are presymptomatic. Subsequently patients develop symptomatic HF (Stages C and D), which is associated with fluid retention (edema), breathlessness, fatigue, exercise intolerance, and death [7]. Transition from presymptomatic HF to symptomatic HF is critically important for patients as it leads to a marked decline in the quality of life and is associated with significant morbidity and mortality $[4,8]$.

Regardless of the cause of DCM, the progression from asymptomatic to symptomatic HF is associated with interdependent, neurohormonal alterations of the sympathetic nervous system (SNS), 
the renin-angiotensin-aldosterone system (RAAS), and the natriuretic peptide (NP) system [9-13]. Neurohormonal activation may initially compensate for impaired cardiac function; however, prolonged activation has deleterious effects on cardiac structure and performance, leading to symptomatic HF associated with edema $[8,13,14]$. An elevation in plasma norepinephrine signifies SNS activation, which occurs at Stage B in clinical and experimental HF and is strongly associated with progression of systolic dysfunction, congestion, and RAAS activation $[15,16]$. The NP system acts to counter the SNS-RAAS by promoting diuresis, natriuresis, and vasodilation [11,17-21]. However, the effects of the NP system are attenuated in advanced HF Stages C and D [22-25]. Activation of RAAS is associated with left ventricular dysfunction, cardiac dilation, sodium and extracellular fluid retention (edema), and cachexia/sarcopenia [26]. Systemic RAAS activation occurs with increased plasma renin activity, which initiates the activation of the primary targets for clinical intervention: angiotensin II (Ang II) and aldosterone [27]. Pharmacological blockade of RAAS has proven to be the mainstream/standard treatment approach for symptomatic HFrEF patients [28-37]. Standard medical therapies include RAAS blockers: angiotensin converting enzyme (ACE) inhibitors (ACE-I), which block the enzymatic conversion of Angiotensin I (Ang I) to Ang II; Ang II receptor blockers (ARB), which block the binding of Ang II to the Ang II type I receptor (AT1); mineralocorticoid receptor antagonists (MRA), which block effects of aldosterone; and angiotensin receptor/neprilysin (NEP) inhibitors (ARNi) [38,39]. Direct renin inhibitors (DRI) are designed to block enzymatically active renin from triggering a pathological alteration of downstream pathways. However, clinical trials have failed to demonstrate the value of renin activity inhibition for improving outcomes for patients with HF on concurrent RAAS blockers or diuretics [40-42]. Complicating the issue is the heterogeneity of patient plasma renin activity levels and their individualized responses to plasma renin activity levels on the background of RAAS blockers or HF progression itself.

Here, we review the role of active renin in HFrEF progression and the potential benefits of renin activity as a diagnostic and/or prognostic plasma biomarker, as well as the potential value of renin inhibitors as a targeted therapy for HFrEF.

\section{Pathways of Renin Generation and Function}

Systemic RAAS maintains vasoconstriction, retains sodium and water, increases arterial blood pressure, and increases myocardial contractility, thus increasing the effective circulating blood volume during physiological and pathological conditions including HF $[43,44]$. Pathologically activated RAAS promotes symptomatic HFrEF [11,45]. The systemic RAAS activation cascade begins with production of prorenin and its conversion/activation to renin (Figure 1), an enzyme that was discovered more than a hundred years ago [46]. Renin activity in plasma increases as HFrEF progresses and is highest with symptomatic HFrEF in patients and animals. The prorenin/renin pair directly and indirectly modulates HFrEF progression. Figure 1 schematically represents a potential role of renin activity in the modulation of HFrEF through direct and indirect actions.

Renin is a monospecific aspartic protease [47] that cleaves glycoprotein angiotensinogen systemically in the circulation or locally at the tissue level to generate angiotensin I (Ang I), which is the key and rate-limiting step in the RAAS activation cascade. Thus, while the concentration of angiotensinogen in plasma is approximately $500-600 \mathrm{pmol}$, Ang I is present in plasma in at least 10,000-folds lower concentration in the 50- to 100-fmol range and Ang II at approximately half of Ang I [48]. It is important to note that circulation levels of angiotensinogen are in the range of the Michaelis-Menten constant for renin; therefore, small modulations in either renin or angiotensinogen levels may significantly alter downstream outcomes [49]. Ang I is the precursor of the physiologically active peptides, Ang II and Angiotensin (1-7) (Ang (1-7)). These are generated by different enzymes, ACE or ACE 2 and NEP; they act through distinct cell surface receptors with opposing biological effects (e.g., vasoconstriction vs. vasodilatation, etc.). However, how these interdependent effects modulate HFrEF is poorly understood. Ang II binds AT1 in targeted tissues and stimulates vasoconstriction and secretion of the steroid hormone aldosterone, which mediates sodium reabsorption and water 
retention [50,51]. Ang (1-7) is a vasodilator that works through the Mas receptor and opposes the actions of increasing Ang II [52-59]. Ang II and Ang (1-7) might also execute their actions through the Ang II type 2 receptor (AT2) in tissue-dependent action [57,60,61]. Ang II actions on the AT2 receptor are thought to be beneficial through vasorelaxation, antihypertrophic, and anti-fibrotic effects. However, AT2 receptor effects on the pathophysiology of HFrEF are predominantly reported during AT1 blockades with ARBs), which are associated with increased plasma renin concentration and activity [62-64]. Despite the extensive experimental and clinical research, the role of AT2 receptor signaling in the failing myocardium remains controversial [65-68]. The balance between Ang II and Ang (1-7) arms may be disturbed during HFrEF progression, both at a systemic level (in circulation) and local level (in tissues). Whether pharmacological alteration of pathological renin activity can restore balance to these pathways remains unclear.

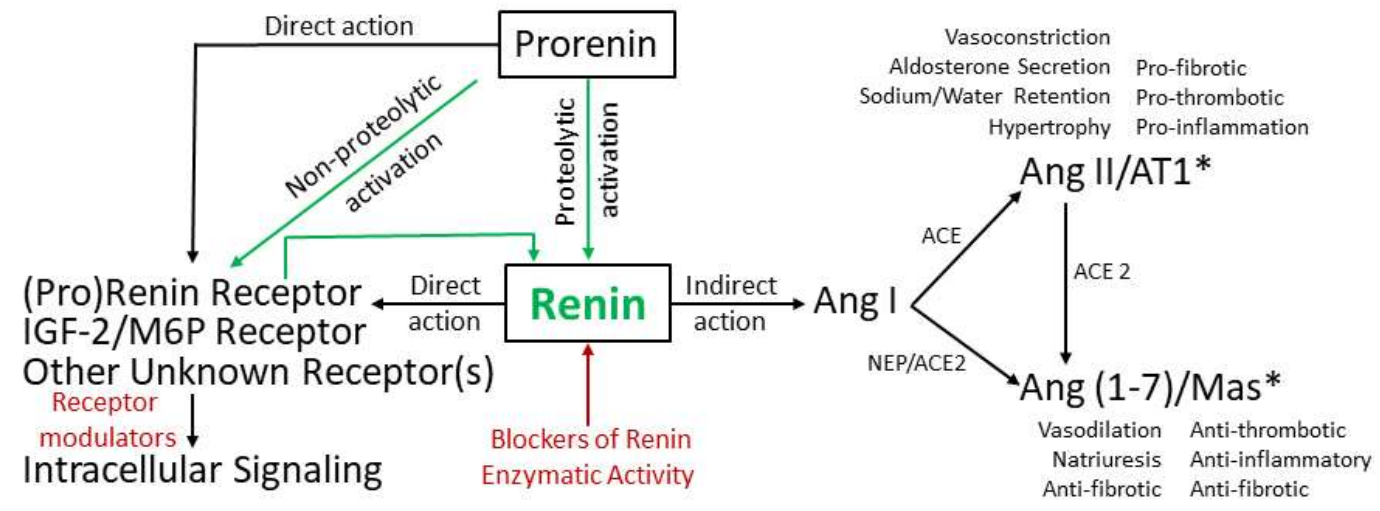

Figure 1. Schematic representation of the potential role of renin activity in the modulation of heart failure with reduced ejection fraction $(\mathrm{HFrEF})$ via direct and indirect effects: Further complicating the physiology of renin is that it has systemic and local effects within the heart. The green arrows represent proteolytic and non-proteolytic conversions of prorenin to enzymatically active renin. Enzymatically active renin has the potential to directly modulate HFrEF progression through binding with receptors such as the (pro)renin receptor and/or IGF-2/M6P receptor. It can also act indirectly through the generation of Angiotensin I (Ang I), which acts through the angiotensin converting enzyme (ACE)-angiotensin II (Ang II)/Ang II type I receptor (AT1) and neprilysin (NEP)/Angiotensin Converting Enzyme 2 (ACE2)-Angiotensin (1-7) (Ang (1-7))/Mas axes or possibly Ang II type 2 receptor (AT2) $\left(^{*}\right.$ ).

In mature mammals, renin is primarily expressed in juxtaglomerular (JG) cells and the collecting duct in the kidney as an enzymatically inactive precursor, prorenin. Prorenin contains a 43-amino-acid prosegment that covers the active cleft of renin to prevent intracellular proteolysis and to provide folding, stability, and extracellular sorting [69-72]. Mechanisms controlling prorenin expression and prorenin/renin secretion have been comprehensively reviewed [44,73-75]. Prorenin/renin expression and secretion are tightly regulated. At the cellular level, they are regulated by calcium ions (inhibitory) [76,77], cyclic adenosine monophosphate (cAMP; stimulatory) [73], and cyclic guanosine monophosphate (cGMP; inhibitory) [78-80]. Ang II levels inhibit renin release through a negative feedback loop, which is activated largely by the influence of the pathologic state or by the use of RAAS medications $[44,81,82]$. At the organ level, they are regulated by two distinct mechanisms: through a renal baroreceptor and by macula densa sodium chloride transport [44,83-85]. Hence, prorenin/renin levels in circulation may be altered in response to stimuli like hypertension, sodium ion concentrations, pharmacological agents including ACE-I, ARBs, loop diuretics, and others [44].

Prorenin potentially can be activated in two ways: proteolytic or non-proteolytic (without proteolytic cleavage). Proteolytic activation involves the actual removal of the prosegment. It occurs in the vesicular network of juxtaglomerular cells by a specific (still unknown) renal protease and potentially in circulation by the kallikrein/Factor XII network [86-93]. Experiments performed in cathepsin B-deficient mice ruled out this intrarenal enzyme as a prorenin convertase [94]. Non-proteolytic 
activation requires conformational change in the prorenin structure, leading to the removal of prosegment from the active enzymatic cleft without proteolytic cleavage, which is achieved after prorenin binds to tissue-expressed (pro)renin receptor, (P)RR [95]. Accumulated data suggest that, while expressed, the majority of prorenin (up to $80 \%$ ) is directly released into circulation, while enzymatically active renin remains stored in the vesicular network awaiting controlled release $[44,74,96]$. Prorenin circulates in blood at concentrations that are ten times higher than active renin [72]. Thus, renin activity in circulation might be modulated by the alteration of active prorenin/renin secretion, stimulation of prorenin activation in the circulation, or inhibition of enzymatic renin activity in circulation. Direct renin inhibitors (DRI) were designed to pharmacologically block enzymatic renin activity in circulation generated proteolytically as well as non-proteolytically [97].

The prorenin/renin network in the kidney is believed to be responsible for activation of RAAS not only systemically in circulation but also locally at the tissue level through prorenin/renin receptor (P)RR-binding mechanisms. (P)RR is a 350-amino-acid protein with a single transmembrane domain, which is widely expressed in various tissues, including the heart and kidney, and acts in a prorenin/renin dependent $[95,98,99]$ and independent fashion [72,100]. After prorenin binds to the (P)RR, non-proteolytically active and fully enzymatically active renin are released back into circulation to trigger systemic RAAS or to work locally at the tissue level to generate Ang I, which converts to the RAAS primary effector peptides, Ang II/Ang (1-7), that are involved in the pathophysiology of cardiac remodeling $[57,101-105]$. Kidney-derived renin or prorenin required for Ang II generation in the cardiac tissue $[43,103,106,107]$ is taken up from circulation through diffusion in the interstitial space or by the (P)RR or other unknown renin receptor(s) [95,101-104,108-112]. (P)RR non-proteolytically activates prorenin also acts as a signaling receptor for the prorenin/renin pair to activate multiple intracellular post-receptor cascades [113-115]. Thus, in cell models, the interaction of (P)RR with prorenin is reported to be important for activation of the mitogen-regulated protein kinase (MAPK) and extracellular signal-regulated kinases 1 and 2 (Erk1/2), leading to production of profibrotic genes, including transforming growth factor- $\beta 1$ (TGF- $\beta 1$ ), plasminogen activator inhibitor type 1 (PAI-1), fibronectin, and collagen $[72,98,99,116,117]$. Aside from prorenin/renin-dependent functions, $(\mathrm{P}) \mathrm{RR}$ is involved in vacuolar-type $\mathrm{H}^{+}$-ATPase (V-ATPase), Wnt/ $\beta$-catenin and potentially other signaling pathways [100]. In addition, (P)RR might be proteolytically shed from membrane surface after cleavage by furin or/and ADAM19 and released into circulation as a 28-kDa soluble protein [118,119]. Plasma levels of soluble (P)RR might reflect renal damage [72,120] and/or the degree of HFrEF [121].

Prorenin/renin secretion is under the control of Ang II through a negative feedback loop. Thus, the magnitude of compensatory prorenin/renin secretion appears dependent on the degree of RAAS activation through the Ang I-Ang II arm. Hence, Ang II generation blockade with ACE-inhibitors and complete blockade of renin activity with DRIs increase the prorenin/renin plasma levels and could potentially have adverse effects through stimulation of the (P)RR-related cascades. This possibility supports the potential of (P)RR blockers as an alternative therapy for DCM-HF and other cardiovascular disorders $[72,99]$. However, it is unclear whether increased prorenin plasma levels result in harmful effects mediated through interaction with the (P)RR [122]. Moreover, the potential of (P)RR blockers is compromised by studies utilizing conditional knockout mouse models of $(P) R R$, which have demonstrated an essential RAAS-unrelated role for $(\mathrm{P}) \mathrm{RR}$ in maintaining cellular homeostasis. Specific deletion of $(\mathrm{P}) \mathrm{RR}$ in podocytes or cardiomyocytes resulted in the rapid onset of organ failure and subsequently animal mortality, suggesting that it is critical for heart and kidney physiology [100]. The nephron-specific knockout of (P)RR resulted in impaired V-ATPase activity and distal renal tubular acidosis in mice but did not affect RAAS [123].

In addition to the interaction with $(\mathrm{P}) \mathrm{RR}$, plasma prorenin/renin might directly contribute to cardiac remodeling and DCM-HF progression by non-enzymatically binding and activating the insulin-like growth factor II/mannose-6-phosphate (IGFII/M6P) receptor, which is highly expressed by cardiomyocytes and cardiac fibroblasts [75,109,124-127]. The actions of prorenin/renin through other still unknown receptors cannot be excluded [103]. 
It has been reported that neonatal cardiomyocytes as well as cardiac fibroblasts are able to bind and internalize recombinant renin and prorenin through IGFII/M6P receptors [109]. The IGFII/M6P receptor is elevated, and its cardiac expression plays an important role in hypertension-induced HF in spontaneous hypertensive rats. In cultured cardiomyoblast $\mathrm{H} 9 \mathrm{c} 2$ cells and in left ventricles of hearts excised from a hypertensive Sprague Dawley rat model with abdominal aorta ligation, IGFII/M6P receptor expression was elevated in response to Ang II-induced apoptosis [128-131]. Prorenin/renin participates in structural remodeling of cardiomyocytes and demonstrate anti-hypertrophic properties [75] via their interaction with the IFGII/M6P receptor. In this way, the drugs modulating prorenin/renin levels potentially counter Ang II-dependent adverse remodeling by directing renin to act non-enzymatically through IGFII/ M6P receptors. In rat myocardial ischemia-reperfusion models, there is hormonal downregulation of cardiac IGFII/M6P receptor mRNA expression during the acute postinfarction phase [75]. In contrast, cardiac IGFII/M6P receptor expression has been shown to be increased in patients with end-stage HF [132]. Renin exerts its effect via the IGFII/M6P receptor by stimulating the elongation of cardiomyocytes [133]. This effect requires the activation of extracellular signal-regulated kinases 1/2 (ERK1/2) [134] and is antagonized by peroxisome proliferator-activated receptor gamma (PPAR $\gamma$ ), which is known to enhance renin gene expression [135]. Thus, renin acting via IGFII/M6P receptor is the first modulator that affects cardiomyocyte length instead of cell thickness, unlike other pro-hypertrophic agents [75]. The effect of renin on the length of cardiomyocytes is attenuated in the presence of M6P, which competes with renin for the IGFII/M6P receptor [135]. Complete M6P/IGF2R knockout results in fetal overgrowth and neonatal lethality. However, the inducible cardiac muscle, skeletal muscle, and liver-specific knockouts of the IGFII/M6P receptor are not lethal and have no obvious phenotype [136]. However, renin expression level was not analyzed in these mice.

Summarizing the above, circulating prorenin/renin has the potential to directly and/or indirectly modulate HF progression (Figure 1). Direct modulation is believed to occur through stimulation of tissue-specific (P)RR and/or IGFII/M6P receptors, which are not solely specific for renin, or other still unknown receptor(s). The potential effect of direct genetic and pharmacological alterations of (P)RR as modulators of HF outcomes have been discussed elsewhere $[72,75,99]$. Indirect modulation of HF occurs through the enzymatic function of active renin and its downstream effects on Ang II and Ang (1-7) production, both in circulation and at the local tissue levels. Imbalance of the two pathways contributes to DCM-HF progression. A pharmacological alteration of renin activity might be beneficial in HF management [99] and results in simultaneous changes of Ang II/Ang (1-7) [137], (P)RR, and IGFII/M6P networks; the interplay of these effects remains to be investigated. We will focus on DRIs that were primarily designed to block enzymatic activity of renin. Beta-blockers and potentially vitamin $\mathrm{D}$ receptor activators, including vitamin $\mathrm{D}$, also lower renin activity and potentially benefit $\mathrm{HF}$ management; however, these modulators are beyond the scope of this review [138-140]. To improve the outcomes of the renin activity-targeted pharmacological approaches aiming to delay or prevent DCM-HF progression, at least three major questions remain to be answered. First, does a pathological increase of renin activity in circulation begin in the presymptomatic stages (A and B) of HFrEF? Second, does an increase in plasma renin activity have a causative effect on DCM-HF progression? Third, does a precise alteration (i.e., normalization) of renin activity in plasma versus a complete suppression of renin activity have differential effects on the progression of HF?

\section{Renin Activity as a Diagnostic and Prognostic Marker}

Plasma renin activity (PRA) and active renin concentration (ARC) longitudinally increase with HF stages in experimental HF to become pathologically elevated in symptomatic HF; levels of each vary between subsets of HF patients with reduced ejection fraction (HFrEF) [15,16,141-145]. Still, the diagnostic and prognostic value of renin enzymatic activity as a predictor and/or modulator of presymptomatic and symptomatic HFrEF, as well as its value for guiding therapy in the absence or presence of a RAAS blockade, remains to be established. 


\subsection{Assays of Plasma Renin Activity}

Experimental studies of renin activity in patients with HFrEF are challenging; patients are heterogeneous, often receive treatments that may modify renin activity, and may have additional comorbidities which differentially affect experimental interventions during clinical trials. For example, therapies that modulate Ang II/aldosterone production and activity affect prorenin/renin levels, renin activity levels, and the potential effects of renin-targeted treatments.

Although circadian rhythm does not affect PRA levels [146], physical activity might. Thus, patients are recommended to sit 10-15 min prior to blood collection [82]. Precautions should be taken during blood sample collection, storage, and handling over assay performance to prevent in vitro proteolysis of prorenin/renin and the non-proteolytic conversion of prorenin to active renin by cryoactivation and/or low $\mathrm{pH}$. Cryoactivation is the process of irreversible conversion of prorenin to active renin in cooled, unfrozen plasma due to unfolding of the prorenin prosegment following by its cleavage by plasma proteases. Considering that the concentration of prorenin in plasma is more than 10 -folds greater than active renin, even a small modulation of the prorenin/active renin ratio in vitro might significantly compromise the final measurements [147-149]. Importantly, techniques and assay protocols used to measure renin activity differ between HFrEF clinical studies (Figure 2), which may impact major conclusions. Reference ranges for renin plasma activity vary; they depend on assay method and differ between commercially available kits. Reference ranges for PRA and ARC have been summarized and published [150].

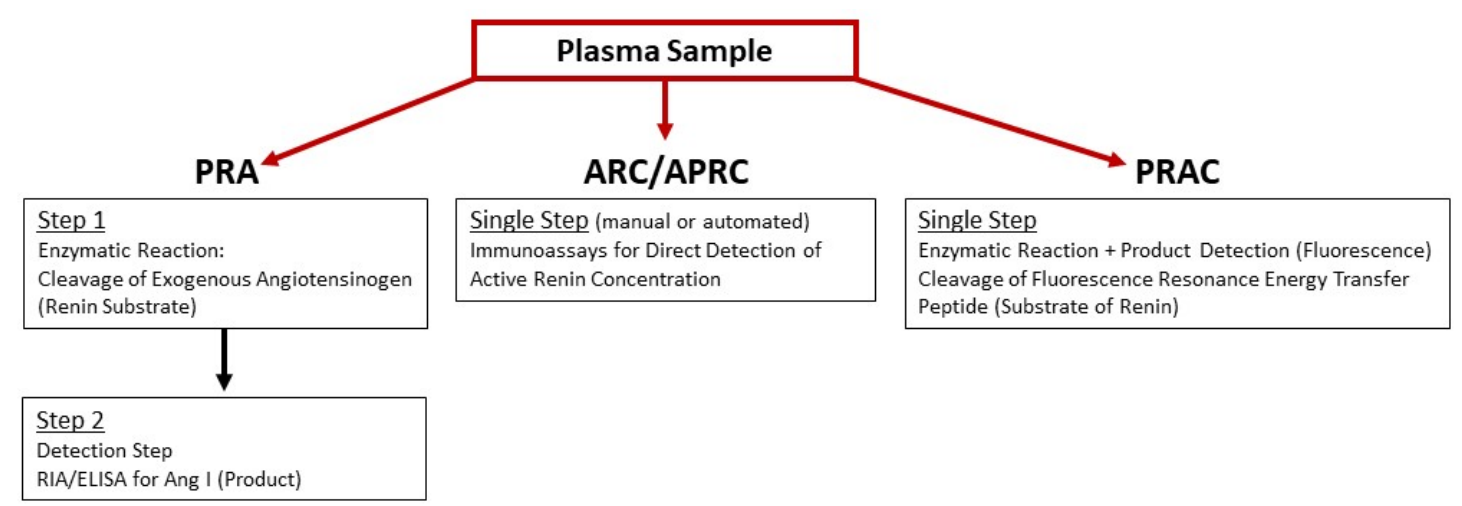

Figure 2. Schematic presentation of assay principles used to measure enzymatic renin activity in plasma samples: Plasma renin activity (PRA); active renin concentration (ARC)/active plasma renin concentration (APRC); and plasma renin activity concentration (PRAC).

\subsubsection{Ang I Generation Assay}

Traditionally in clinical studies, renin enzymatic activity, abbreviated as PRA, is assayed by a 2-step process measuring the potential of a patient's plasma sample to convert exogenous angiotensinogen (substrate) to Ang I (product) during in vitro incubation, followed by measurement by radioimmunoassay (RIA) or enzyme-linked immunosorbent assay (ELISA) of the generated Ang I. However, the Ang I generation step is time-consuming and time-sensitive. Depending on active renin levels in plasma, this step might take from 3 to $18 \mathrm{~h}[147,151]$. Moreover, PRA measurements could be altered by the amount of endogenous angiotensinogen level in plasma samples.

\subsubsection{Immunoassay for Active Renin}

The second method for estimation of enzymatically active renin in plasma samples is angiotensinogen-independent and technically more convenient. This assay measures an active renin concentration, abbreviated as ARC/APRC, using an antibody that is specifically directed against the active site of renin and. therefore, capable to distinguish active renin from inactive prorenin $[99,151,152]$. In general, these assays use principles of sandwich immunoassay; monoclonal 
capture antibody recognizes both active renin and prorenin, followed by a detection step with a labeled monoclonal antibody toward active renin. Several detection systems have been developed and are comprised of either manual or automated immunoassays for the quantification of ARC/APRC [152-156].

\subsubsection{Renin-Specific Substrate Cleavage Assay}

An alternative strategy for renin enzymatic activity quantification utilizes exogenous fluorescence resonance transfer (FRET) peptide substrates of renin based on the octa- to deca-peptides derived from the N-terminal sequence of angiotensinogen, labeled with quencher/fluorophore pairs-DABCYL/EDANS [157,158], Dnp/Amp, or QXLTM520/5-FAM (SensoLyte 390 or SensoLyte 520 assay kit, AnaSpec, Fremont, CA, USA). Cleavage of the FRET substrate results in the recovery of quenched fluorescence that can be directly monitored and conveniently quantified. Results of this assay are expressed as active enzyme concentration in $\mathrm{nM}$ or $\mathrm{ng} / \mathrm{mL}$. The QXL pair is superior to the other two: 5-FAM fluorophore has higher brightness and stability, and its fluorescence can be monitored with minimal autofluorescence background of test compound, cell components. and plasma proteins (SensoLyte 520 assay kit, AnaSpec, Fremont, CA, USA). The FRET-QXL TM520/5-FAM peptide substrate was optimized by the AnaSpec, Inc. for human, mouse, or rat renin. Specificity of substrate cleavage was validated with several known renin inhibitors. Commercially available kits containing FRET-QXL ${ }^{\mathrm{TM}} 520 / 5-\mathrm{FAM}$ substrates are designed for in vitro screening of renin inhibitors, are marked "for research use only", and are not validated by the company to measure renin enzymatic activity in plasma. Hence, normal values and ranges for renin are not established for this assay. and clinical comparisons with PRA and ARC assays have not yet been performed. Although nonspecific cleavage of this FRET substrate in plasma could not be excluded, a supplementation of plasma samples with a combination of ethylenediaminetetraacetic acid (EDTA) and serine protease inhibitors phenylmethylsulfonyl fluoride (PMSF) or aprotinin chelates zinc/calcium ions required for activity of $\mathrm{ACE}$ and angiotensinase $\mathrm{A}$ and inactivates chymases and angiotensinase B. FRET-QXLTM520/5-FAM containing kits were successfully adopted by several laboratories for the direct measurement of plasma renin enzymatic activity [145,159-165]. Importantly, the assay detected changes in plasma renin activity concentration relative to pathophysiological stresses associated with renal autograft ischemia-reperfusion injury [159], response to ARBs in normal and diabetic C57BL/6 mice [163], and chronic suppression of plasma renin activity in experimental mouse model of HFrEF with DRI aliskiren [165]. We abbreviate this assay as PRAC (plasma renin activity concentration) in order to distinguish from PRA and ARC/APRC.

\subsection{Prognostic Value of Plasma Renin Activity in HFrEF}

Over the past decade, the prognostic value of PRA in HF has been extensively evaluated and reported. PRA was reported to be an independent prognostic marker in prospectively enrolled patients with $\operatorname{HFrEF}(n=996)$, irrespective of medical treatment, which was additive to $\mathrm{N}$-terminal-pro hormone B-type natriuretic peptide (NT-proBNP) levels and ejection fraction (EF) [166]. The independent prognostic value of PRA was reported for chronic HF patients with chronic kidney disease comorbidity. PRA in combination with NT-proBNP plasma levels identified a subgroup of high risk patients, who might benefit from more intensive care [167]. Higher PRA levels were associated with a greater likelihood for prevalence of congestive HF in a large diverse cross sectional study on hypertensive individuals [168]. Elevated PRA levels demonstrated increased risk for congestive HF and a trend toward higher mortality among patients with systolic blood pressure (SBP) $\geq 140 \mathrm{mmHg}$, but this was not true for individuals with SBP $<140 \mathrm{mmHg}$ [169]. PRA was significantly elevated in ambulatory chronic HFrEF patients and in acute HFrEF patients [170]. All trials described above contain patients with concurrent HF medications (ACE-I, ARB, ARNi, etc.). The Studies of Left Ventricular Dysfunction (SOLVD) trial showed groups (control vs. HFrEF) could be stratified based on elevated PRA levels without prior exposure to ACE inhibitors but did not exclude diuretics [16]. Similarly, others reported that HFrEF patients on diuretics were more likely to have elevated PRA [171]. However, the results 
from Val-HeFT trials report that PRA remains a prognostic marker even in the presence of ACE inhibitors, which are known to increase PRA levels [143]. ARC was reported to be superior to PRA for the evaluation of HF severity and for independently predicting survival in HF patients who were hospitalized for management of HFrEF and were already on ACE inhibitor or ARB medications [153]. Most recently, ARC was found to be a potential biomarker for HFrEF, which had value in addition to NT-proBNP and NYHA classification, to subclassify HFrEF patients receiving RAAS blockers into HFrEF phenotypes that required adaptive therapeutic interventions [156].

Although differences between PRA and ARC/APRC are not clearly established in HF, specific measures of plasma renin activity may be useful for identifying individuals for whom titrated doses of renin inhibitors may attenuate the progression of HFrEF.

Our unpublished pilot data show that a pathological elevation of PRAC precedes the development of edema (symptomatic HFrEF) in a subset of patients with reduced systolic function with or without symptomatic HF (Figure 3A). There was no significant difference in medical management between $\mathrm{rEF}$ groups with or without symptomatic HF; an equal percentage of patients received beta-blockers, ACE inhibitors, or ARBs [25,82]. Patients with a significant increase in PRAC levels compared to healthy controls might benefit from the addition of DRI to standard HF therapy. Patients in this study were characterized by enzymatic downregulation of the NP system, with elevated plasma levels of NEP, atrial natriuretic peptide (ANP), B-type natriuretic peptide (BNP), and cGMP and reduced plasma levels of the pro-natriuretic peptide convertase, corin [25]. There was a positive correlation between PRAC and plasma N-terminal-pro atrial natriuretic peptide (N-ANP) (Figure 3B).
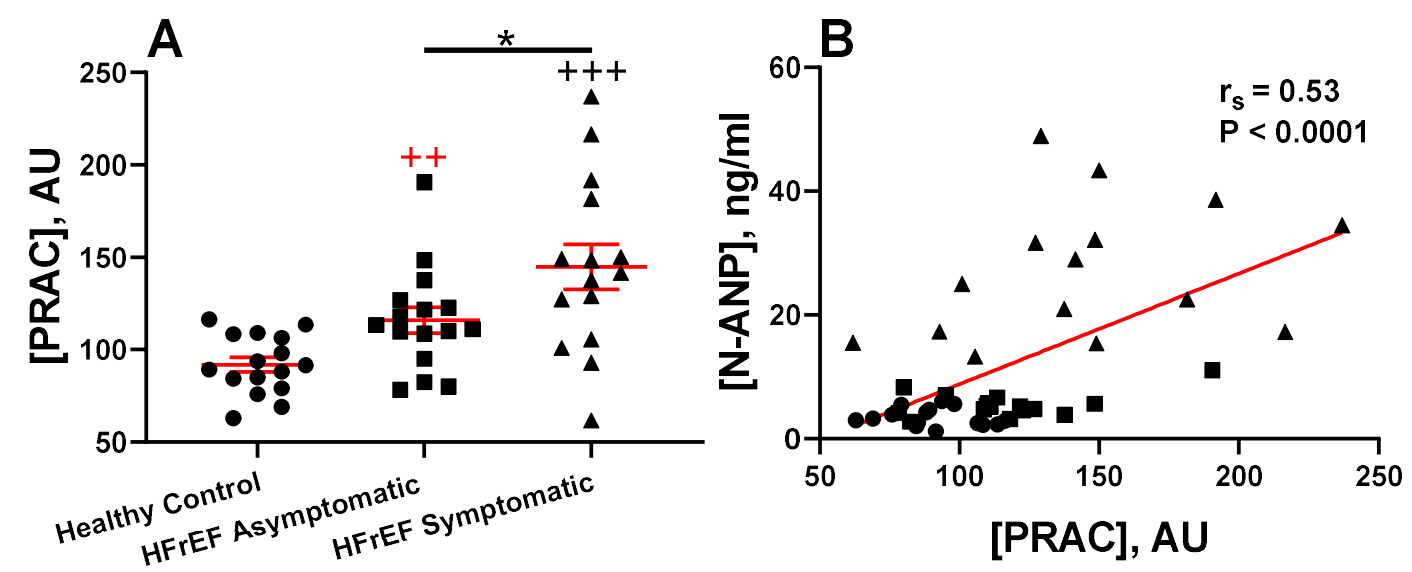

Figure 3. Plasma renin activity concentration (PRAC) in healthy control and heart failure (HF) patients with systolic dysfunction: (A) Plasma samples of healthy control patients (normal ejection fraction, $\mathrm{EF}$ ) and patients with reduced $(\mathrm{rEF})$ with and without symptomatic HFrEF. (B) Spearman correlation of PRAC to plasma N-terminal pro-atrial natriuretic peptide (N-ANP). All patients were males and 50-70 years old. Groups were healthy control subjects $(n=16)$, HF with reduced ejection fraction (HFrEF) asymptomatic $(n=16)$, and HFrEF symptomatic $(n=15)$. Venous blood samples were collected using EDTA-aprotinin tubes. This investigation was a part of our previously reported study [25]. This study was approved by the Institutional Review Board, and all subjects gave their informed consent for inclusion before they participated in this study [25]. Data represent mean \pm SEM. $++p<0.01$, (red, Control vs. Asymptomatic) $+++p<0.0001$ (black, Control vs. Symptomatic), ${ }^{*} p<0.05$ (Asymptomatic vs. Symptomatic HFrEF). AU = arbitrary units. Comparisons between groups were calculated using the Mann-Whitney test. Statistical analysis was performed with GraphPad Prism 8.0.2 (GraphPad Software, San Diego, CA, USA). $p>0.05$ was considered significant.

\subsection{Renin Activity in Idopathic and Experimental (Genetic or Induced) Animal HFrEF Studies}

The diagnostic value of PRA is evident in canine HF associated with idiopathic DCM (HFrEF) [172]. DCM is one of the most common heart diseases in dogs and carries a poor prognosis; it is characterized by atrial/ventricular dilatation and myocardial systolic/diastolic dysfunction [173-175]. Similar to humans, 
dogs with DCM often progress to symptomatic HF characterized by dyspnea caused by pulmonary edema and/or pleural effusion and by abdominal distention caused by ascites [172,174,176-179]. Dogs with DCM may have cough, depression, weight loss, panting, syncope, and polydipsia. Similar to humans, plasma NT-proANP levels are elevated in dogs with symptomatic HFrEF but not in dogs with non-symptomatic DCM [174]. PRA and plasma aldosterone levels were reported to be significantly increased above normal levels in dogs with symptomatic HFrEF $[15,142,174]$. PRA but not aldosterone levels were elevated in a subset of dogs with asymptomatic HFrEF [142].

DCM and symptomatic HFrEF have been reported by echocardiography and histological studies of nonhuman primates. However, PRA and ANP/BNP or levels for other HF markers were not reported [180-184].

Translational mouse and rat models of DCM-HF are invaluable experimental tools for probing single-variable research questions in a mammalian living system, without other confounders associated with clinical studies $[185,186]$. Fortunately, the key features of the prorenin/renin network are rather similar in humans and animals [74]. Still, the number of renin-producing kidney cells, the rate of intracellular prorenin processing, the rate of prorenin/renin activation and secretion, and the rate of angiotensinogen cleavage by active renin are species-specific $[74,187]$. Unlike other mammalian species, mice express one (Ren-1, ortholog of human Ren gene) or two renin genes (Ren-1 and Ren-2, tandem duplication of Ren-1, encodes non-glycosylated form), depending on the strain [188]. Although plasma renin activity and aldosterone levels showed no significant differences between one renin and two renin gene mice, $\mathrm{C} 57 \mathrm{Bl} / 6, \mathrm{C} 3 \mathrm{H}$, and $\mathrm{BALB} / \mathrm{c}$ mouse strains, which do not harbor the second renin gene (Ren-2), are preferential for translationally relevant experimental DCM-HF studies as they more closely represent the human condition $[81,189,190]$. Several renin knockout and transgenic animal models have been generated and described. Unexpectedly, renin null rats (Ren-1 -/-) were viable and showed a profound decrease in blood pressure and abnormal renal morphology with decreased glomeruli numbers and impaired renal function [191]. Mice lacking the Ren-1d gene display reduced plasma active renin levels, an increase in prorenin levels, abnormal renal morphology, and a sexual dimorphic hypotension in females [192]. Ren-2 gene is functionally different and may not complement the effects of Ren-1d gene in these mice. Mice lacking Ren-2 were viable and healthy without any abnormality in kidney morphology [193]. To overcome potential translational discrepancies between rodents and humans, transgenic humanized models overexpressing both human renin and human angiotensinogen have been developed in several laboratories [194-199]. However, since these models have a hypertensive phenotype, which alters HF progression, their value for DCM-HF studies is limited.

Experimental animal studies support the diagnostic value of plasma renin activity (PRA) in symptomatic HF and HFrEF progression. PRA levels were elevated more than six-fold in rapid atrial pacing-induced symptomatic HFrEF in pigs and were resistant to treatment with ACE inhibitors, AT1 blockers, or a combination of both [200]. PRA levels were about four-folds elevated in a sheep HF model induced by rapid ventricular pacing [201]. In both models, PRA elevation was accompanied by a several-fold elevation in plasma levels of norepinephrine, epinephrine, and aldosterone. PRA levels were also elevated in dogs with advanced HF-induced rapid ventricular pacing [202]. In a drug-naïve, genetic model of HF in male rats (SHHF/Mcc-facp), PRA, ANP, and aldosterone plasma levels progressively increased with age, dilation of cardiac chambers, and development of overt HF. In this model, hypertension, PRA, and male sex were independent factors contributing to cardiac hypertrophy and HF. In female rats, the progression of PRA elevation and HF was delayed in comparison with males [203]. PRA and aldosterone plasma levels were pathologically elevated in a genetic mouse model of progressive cardiac dysfunction, leading to lethal arrhythmias due to a cardiac-specific, dominant negative form of neuron restrictive silencer factor (dnNRSF-Tg) [204]. PRA was significantly elevated in a transgenic (CSQ-tg) HF mouse model of progressive DCM, which was characterized by abnormal calcium levels, hypertrophy, cardiac fibrosis, and poor contractility and resulted in overt HF and death [205-207]. 
We recently reported that PRAC levels are elevated prior to edema formation and reflect HFrEF progression in female mice with DCM due to a transgenic, dominant-negative CREB transcription factor $[18,145,164,208,209]$. Similar to humans, these DCM mice pass through all four Stages A-D of HF in a sex-related manner from Stage A (risk without abnormalities) to progressively declining contractile function and increasing heart dilation (Stage B) to the development of peripheral and pulmonary edema and pleural effusions with increases in plasma ANP and BNP (Stage C) to the onset of severe HF and death (Stage D) $[145,210]$. Pathological PRAC, plasma Ang II, and aldosterone levels increased with the progression of systolic dysfunction, cardiac remodeling, edema, and stages of HF in a sex-related fashion (Figure 4). Despite elevated PRAC levels, systolic and diastolic blood pressure were not elevated and kidney function (plasma BUN and creatinine) was within normal limits [145]. In female mice with DCM, the pathological rise in PRAC levels preceded the development of edema (Stage C) and likely contributed to the early demise of female verses male DCM mice (median survival 13.8 verses 20 weeks). Although the RAAS may be affected by sex [211,212], ovariectomy did not influence PRAC, systolic function, lung water retention, and survival [145]. Potentially, the increased PRAC levels in female mice with DCM may be driven by sex-related differences in upstream pathways related to the kinin-kallikrein/Factor XII network, which may regulate enzymatic prorenin activation $[92,93]$.

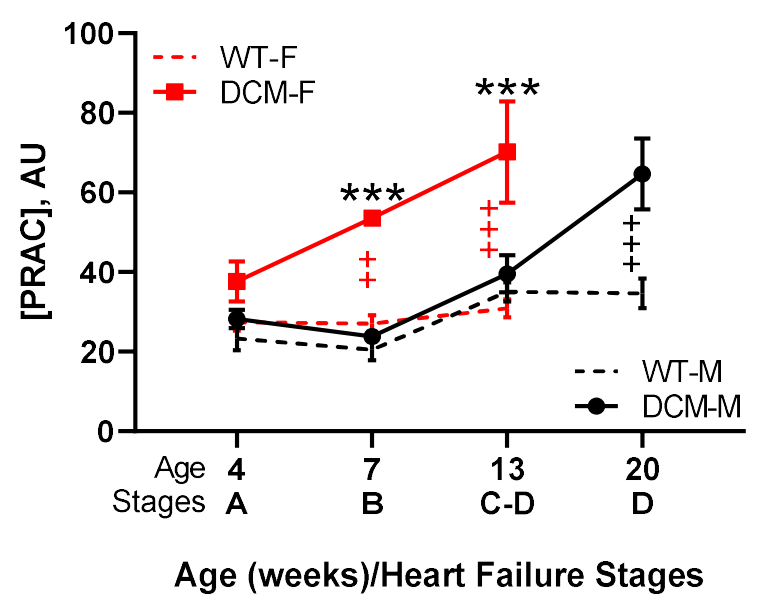

Figure 4. PRAC increases in a sex-dependent manner throughout the course of HFrEF progression in male and female mice with dilated cardiomyopathy (DCM). This figure combines published and unpublished data from our previously reported study [145]. Wild type males (WT-M): $n=5-8 /$ age group; WT females (WT-F): $n=6-7 /$ age group; DCM males (DCM-M): $n=7-8$ /age group; DCM females (DCM-F): $n=6-8$ /age group. +/red-Difference between WT and DCM females: $++p<0.01$, $+++p<0.001 ;+/$ black-Difference between WT and DCM males: $+++p<0.001 ; * /$ black-Difference between DCM females and DCM males: ${ }^{* * *} p<0.001$. Time-dependent differences between sexes (male vs. female) and differences between genotypes (WT vs. DCM) were analyzed by two-way ANOVA with the Bonferroni posttest correction using GraphPad Prism 8.0.2 (GraphPad Software, San Diego, CA, USA). Data are expressed as mean \pm SEM. All animal study activities were approved [145].

\section{Renin Activity as a Bio-Target for Pharmacological Intervention Using Direct Renin Inhibitors (DRI) in HFrEF}

The pharmacological class of direct renin inhibitors (DRI), which are used predominantly to treat hypertension, work through high-efficiency binding to active renin [213]. As the initial step in the RAAS pathway, direct blockage of the enzymatic activity of renin has the theoretical benefit of modulating downstream molecules and receptors. In both human and animal trials, aliskiren continues to be the most frequently studied DRI; however, newer drugs are in development, such as ACT-178882/MK-1597 [214] and TAK-272 (imarikiren) [207,215] as monotherapies or in combination with other RAAS inhibitors. 


\subsection{In Clinical HFrEF}

First and second generation DRIs failed due to their short durations of action, low oral bioavailability, and poor efficacy [216]. In 2007, aliskiren, a third generation orally active DRI was approved by the U.S. Food and Drug Administration for the treatment of hypertension [216]. Soon thereafter, this small-molecule inhibitor was enrolled in several clinical trials [40,41,217-219] to investigate the clinical effect of the drug against and in combination with standard therapeutic medications for the treatment of HF. The clinical trials were largely neutral [40-42,218-220], with most reporting no reduction in cardiovascular deaths or rehospitalizations due to DRI or the combination of RAAS blockers (ACE-I, beta-blockers, etc.). Some trials even stopped prematurely due to increases in adverse events compared to control groups. A retrospective critical evaluation of these clinical trials revealed inconsistent enrollment criteria which included HF with reduced ejection fraction (HFrEF) ranging from a $\leq 35 \%$ to $45 \%$ variation in the initial HF stage based on the New York Heart Association (NYHA) classification and mixed comorbidities. Only the Additive Renin Inhibition with Aliskiren on Renal Blood Flow and Neurohormonal Activation in Patients with Chronic Heart Failure and Renal Dysfunction (ARIANA-CHF-RD) trial enrolled patients with mild to severely increased plasma renin activity (PRA) at baseline [219]; aliskiren successfully lowered PRA in the treatment group after 26 weeks compared to placebo controls. However, it is important to note that there was no classification between the outcomes of trial groups based on PRA range at enrollment (mild, moderate, and severe compared to the normal level) that have been reported. One explanation for this is that standard HF therapeutics (ACE-I, ARB, beta-blockers, diuretics, etc.) increase plasma renin activity levels [82,221]; thus, the utility of these values require additional research. Also, females were significantly underrepresented, with only $15-23 \%$ of the patient population. A sub-study of the Six Months Efficacy and Safety of Aliskiren Therapy on Top of Standard Therapy, on Morbidity and Mortality in Patients with Acute Decompensated Heart Failure (ASTRONAUT) trial revealed that aliskiren significantly reduced PRA levels in a one-year follow-up. Another major conclusion was that aliskiren treatment had a greater effect on PRA, more so than plasma aldosterone modulation, and lowered NT-proBNP levels throughout treatment. PRA was also found to correlate with neurohormonal status as a prognostic and stable biomarker, with elevated PRA corresponding to the highest risk group [222]. Considering these reviews, it is possible that a therapeutic advantage of aliskiren toward HF was overlooked due to improper identification of the patient subpopulations and the limitations of clinical PRA testing versus ARC or PRAC as discussed earlier. Alternatively, these trials may have failed because they were not biomarker-guided to treat patients with increased PRA or because they were initiated when HF was too advanced (HF Stages C and D). Another explanation is that patients might not have received benefits from DRI because they already were on maximally tolerated doses of standard ACE inhibitors and ARBs [219,223].

Studies with DRI revealed that renin aggravates HF indirectly though generation of Ang I and activation of Ang I-Ang II-ATI axis or directly via renin receptors. The DRI, aliskiren has a dose-related effect on blood pressure modulation in patients [224,225]. It has been proven safe in normotensive patients from 40-640 $\mathrm{mg}$ with daily oral administration [226]. Most studies utilize a loading protocol with initiation at $150 \mathrm{mg}$ for 1-2 weeks, followed by an increase to $300 \mathrm{mg}$ daily dose per person. If not tolerated due to side effects or hypotension, reduction to $150 \mathrm{mg}$ maintenance is standard. Aliskiren was shown to decrease Ang II levels in people starting at a single dose as low as $40 \mathrm{mg}$ and can suppress levels by $75-89 \%$ after one week of daily administration [227]. Results from the Aliskiren Observation of Heart Failure Treatment (ALOFT) trial using the lower common dose of aliskiren $(150 \mathrm{mg} /$ daily) showed positive results when used in combination with standard therapies. Aliskiren was well-tolerated when administered in combination with ACE inhibitors, beta-blockers, or MRAs. Importantly, blood pressure was not modulated by aliskiren treatment alone when compared to the placebo $[228,229]$.

Increased plasma renin activity enhances aldosterone production. The degrees of increase in plasma renin concentrations and plasma aldosterone levels correlate with prognosis in patients with 
HF $[11,16,230]$. Aldosterone has an avid, renal sodium-water retaining effect and is considered a key hormone in the development of HF through its pleiotropic actions mediated by mineralocorticoid receptors [51]. Aldosterone has adverse effects on the cardiovascular system, including prevention of myocardial neuronal reuptake of norepinephrine (thereby enhancing sympathetic drive) and potentiation of fluid overload and electrolyte imbalance [9,51,231,232]. Clinical trials utilizing mineralocorticoid receptor antagonists (MRA) with survival benefits support the concept that aldosterone activation is deleterious in symptomatic HFrEF (Stages C and D) [31]. MRAs reduce the harmful effects of hyper-aldosteronism on the cardiovascular system and have a potassium-sparing diuretic effect.

Although the majority of DRI studies have focused on patients with rEF for enrollment criteria $[41,42,217-219,228]$, newer trials are starting to consider targeting renin activity in patients with preserved EF [233]. Additionally, the systemic nature, growing comorbidities and classification of HF need to be considered when attempting to modulate RAAS/NP in HF [38,39,234-237]. This review is limited to HFrEF; however, further investigation encompassing the additional causes of HF should be considered.

\subsection{In Animal Models of HFrEF}

There are growing numbers of experimental studies addressing the effect of renin activity inhibition in animal models of cardiomyopathy leading to symptomatic HF. These studies assess the outcomes of interventions that targeted renin activity solely or versus dual renin system interventions. In myocardial infarction (MI)-induced HF models, comparative treatments with ACE inhibitor, aliskiren, or a combination of both revealed that the synergism of the drug combination was more beneficial than when either agent was used alone [238]. In an induced, diabetic cardiomyopathy mouse model, aliskiren prevented cardiac systolic and diastolic dysfunctions similar to ARBs and ACE inhibitors, significantly lowered circulating pro-inflammatory cytokine levels, and protected against oxidative stress [239]. In a mouse model of acute MI, aliskiren treatment improved systolic dysfunction and prevented remodeling, apoptosis, and hypertrophy of the left ventricle [240]. Similar effects were seen in a doxorubicin-induced cardiomyopathy rat model [241]. In a randomized, blinded experimental study we found, that biomarker-guided treatment with aliskiren $[145,210]$, in which PRAC levels were elevated at presymptomatic Stage B HF, reduced the progression of cardiomyopathy, delayed the development of edema, and significantly prolonged life [165].

Several experimental studies suggest that aliskiren might work not only through Ang II but also alternatively through the Ang (1-7) arm. In hypertensive rats, $50 \mathrm{mg} / \mathrm{kg} / \mathrm{day}$ subcutaneous aliskiren tended to reduce plasma Ang II and significantly reduced plasma Ang (1-7) levels compared to vehicles [242]. In another study, aliskiren (50 mg/kg/day) upregulated the expression of AT1 and MAS receptors and downregulated the expression of AT2 receptor in rats with diabetic nephropathy [243]. Modulation of Ang (1-7) by aliskiren was reported in patients with nondiabetic chronic kidney disease [244].

In addition to being a direct inhibitor of enzymatic renin activity, aliskiren (administrated orally at $10 \mathrm{mg} / \mathrm{kg} /$ day in drinking water) was reported to increase cardiac bradykinin and kallikrein gene expression levels in TGR(mRen-2)27 rats independent of its effects on renin inhibition [245]. A subsequent study reported that aliskiren $(10 \mathrm{mg} / \mathrm{kg} /$ day) protected the rat hearts from myocardial ischemia-reperfusion injury via a B2-receptor- and AT2-receptor-mediated mechanism [246]. When aliskiren was administrated subcutaneously (SC) via osmotic mini pumps in doses that do not modulate blood pressure, its effects on local tissue's modulations were reported. Thus, in diabetic transgenic mouse models, SC aliskiren administration resulted in improvements in albuminuria and renal fibrosis by regulating inflammation and the alteration of collagen synthesis and degradation [247]. It also improved insulin resistance and adipose tissue dysfunction in type 2 diabetic mice through an increase in insulin sensitivity, insulin secretion, and adipocyte differentiation and a reduction of oxidative stress [107]. In an Apo E-/- C57/BL6 mouse model, SC aliskiren administration results in an increased 
number and function of pro-angiogenic cells in mice and prevented atherosclerotic lesion formation in spleen-derived pro-angiogenic cells. The effect was independent from blood pressure through lowering (P)RR expression [248,249]. The results of these studies strongly suggest that the effect of DRI on renin activity in vivo could not be simply estimated by the changes in plasma levels of Ang I and Ang II and that PRA, ARC/APRC, or PRAC assays should be used.

Of the newer DRI drugs, only limited in vivo studies have been reported. In human-renin and human-angiotensinogen double transgenic $(\mathrm{dTg})$ rats, TAK-272 was found to have a greater potency and a six-fold increase in oral bioavailability when compared to aliskiren for modulating blood pressure [215]. In a calsequestrin female transgenic (CSQ-Tg, C57BL/6 $\times$ DBA/2 hybrid) mouse model of severe symptomatic HF with high mortality, oral daily TAK-272 in a dose-dependent fashion prolonged the survival and, at the highest dose $(300 \mathrm{mg} / \mathrm{kg})$, showed a significant reduction in elevated PRA, decreased cardiac hypertrophy, a two-fold increase in left ventricular EF, decreased plasma NT-proBNP levels, and decreased lung congestion-clearly signifying cardioprotection during HF [207]. In a separate cohort of CSQ-Tg mice treated with $300 \mathrm{mg} / \mathrm{kg}$ TAK-272 for one week, there was no difference in blood pressure compared to vehicle controls [207].

\section{Conclusions}

The potential value of renin activity as a diagnostic and/or prognostic biomarker of HFrEF when assessed as PRA, ARC, or PRAC is evident in a growing number of animal and clinical studies. Still, studies evaluating renin activity as a predictor of HF in presymptomatic patients are lacking. Nevertheless, experimental animal studies strongly support the potential therapeutic benefits of precisely titrating suppression of renin activity in symptomatic HFrEF. However, clinical advancement of DRIs has slowed with the termination of the aliskiren HF trials due to side effects and poor outcomes. Clinical trial enrollment of patients with advanced HF stages ( $C$ and D) may account for some inconsistencies in evaluating renin activity levels in HFrEF patients. In addition, the dose-related effects of aliskiren in HF studies have not been well-established. Most studies have defaulted to the traditional hypertensive doses of 150-300 mg/kg/daily rather than considered the benefits of lower doses observed from the experimental studies. Currently, there are new DRIs and (P)RR inhibitors under development, which suggest that the cardiovascular field is not prepared to give up on the promising pharmacologic potential of renin activity as a bio-target to delay HF progression. However, it is important to consider that future HFrEF trials will unlikely be designed in the absence of currently recommended treatments, including other RAAS blockers. To improve both the preclinical and clinical uses of renin activity as a reliable HFrEF biomarker and bio-target, consensus should be reached over laboratory assays used in different clinical studies. It is preferable that patient plasma renin activity levels be obtained prior to initiation of RAAS blockers or diuretic therapy, as these medications may elevate levels. The optimal method of diagnosing and monitoring enzymatic renin activity levels in patient plasma samples will allow for improved outcomes through the use of individualized/precision medicine approaches in HF clinical management. Significant consideration for proper trial enrollment criteria should be paramount, as experimental studies indicate that DRIs are efficacious when applied to the proper subgroups.

Author Contributions: Conceptualization, management, and design, G.L.R. and I.P.G.; formal analysis R.D.S., G.L.R., and I.P.G.; writing-primary draft, R.D.S. and I.P.G., writing—subsection drafts, R.M.M. and R.T.; writing—critical review and revision, G.L.R.; writing—review and editing, R.D.S., R.M.M., R.T., G.L.R., and I.P.G.; funding acquisition, G.L.R. and I.P.G.; all authors have read and approved the final manuscript.

Funding: This work was supported in part by the National Institutes of Health (Grants HL92750 and NS089707 to G.L.R. and HL115036 to I.P.G.).

Conflicts of Interest: UA Tech Launch Arizona, along with R.D.S., R.M.M., R.T., G.L.R., and I.P.G., have filed patents related to this research. Otherwise, the authors declare no competing interests. 


\section{Abbreviations}

\begin{tabular}{|c|c|}
\hline $\mathrm{HF}$ & Heart Failure \\
\hline $\mathrm{rEF}$ & Reduced Ejection Fraction \\
\hline DCM & Dilated Cardiomyopathy \\
\hline ACC & American College of Cardiology \\
\hline AHA & American Heart Association \\
\hline SNS & Sympathetic Nervous System \\
\hline NP & Natriuretic Peptide \\
\hline ANP & Atrial Natriuretic Peptide \\
\hline BNP & B-Type Natriuretic Peptide \\
\hline NT-proANP & N-terminal-pro ANP \\
\hline NT-proBNP & N-terminal-pro hormone BNP \\
\hline RAAS & Renin-Angiotensin-Aldosterone System \\
\hline $\mathrm{ACE}$ & Angiotensin Converting Enzyme \\
\hline ACE-I & Angiotensin Converting Enzyme Inhibitor \\
\hline ACE2 & Angiotensin Converting Enzyme 2 \\
\hline Ang I & Angiotensin I \\
\hline Ang II & Angiotensin II \\
\hline Ang (1-7) & Angiotensin (1-7) \\
\hline $\mathrm{ARB}$ & Angiotensin II Receptor Blockers \\
\hline AT1 & Angiotensin II Type 1 Receptor \\
\hline AT2 & Angiotensin II Type 2 Receptor \\
\hline Mas & G Protein-Coupled Receptor Mas \\
\hline MRA & Mineralocorticoid Receptor Antagonist \\
\hline $\mathrm{ARNi}$ & Angiotensin Receptor Neprilysin Inhibitors \\
\hline DRI & Direct Renin Inhibitor \\
\hline NEP & Neprilysin \\
\hline JG & Juxtaglomerular \\
\hline cAMP & Cyclic Adenosine Monophosphate \\
\hline cGMP & Cyclic Guanosine Monophosphate \\
\hline$(\mathrm{P}) \mathrm{RR}$ & (Pro)Renin Receptor \\
\hline MAPK & Mitogen-Regulated Protein Kinase \\
\hline Erk1/2 & Extracellular Signal-Regulated Kinase 1 and 2 \\
\hline TGF- $\beta 1$ & Transforming Growth Factor- $\beta 1$ \\
\hline PAI-1 & Plasminogen Activator Inhibitor Type 1 \\
\hline IGFII & Insulin-Like Growth Factor II \\
\hline M6P & Mannose-6-Phosphate \\
\hline $\operatorname{PPAR} \gamma$ & Peroxisome Proliferator-Activated Receptor gamma \\
\hline PRA & Plasma Renin Activity \\
\hline ARC & Active Renin Concentration \\
\hline APRC & Active Plasma Renin Concentration \\
\hline PRAC & Plasma Renin Activity Concentration \\
\hline RIA & Radioimmunoassay \\
\hline ELISA & Enzyme-Linked Immunosorbent Assay \\
\hline EDTA & Ethylenediaminetetraacetic Acid \\
\hline PMSF & Phenylmethylsulfonyl Fluoride \\
\hline $\mathrm{AU}$ & Arbitrary Units \\
\hline SBP & Systolic Blood Pressure \\
\hline SOLVD & Studies of Left Ventricular Dysfunction \\
\hline NYHA & New York Heart Association \\
\hline
\end{tabular}




$\begin{array}{ll}\text { ARIANA-CHF-RD } & \begin{array}{l}\text { Neurohormonal Activation in Patients with Chronic Heart Failure and } \\ \text { Renal Dysfunction } \\ \text { Six Months Efficacy and Safety of Aliskiren Therapy on Top of Standard } \\ \text { Therapy, on Morbidity and Mortality in Patients with Acute } \\ \text { ASTRONAUT }\end{array} \\ & \begin{array}{l}\text { Decompensated Heart Failure } \\ \text { Aliskiren Observation of Heart Failure Treatment }\end{array} \\ \text { BUN } & \text { Blood Urea Nitrogen } \\ \text { SEM } & \text { Standard Error of the Mean } \\ \text { SC } & \text { Subcutaneous } \\ \text { dTg } & \text { Double Transgenic } \\ \text { CSQ } & \text { Calsequestrin }\end{array}$

\section{References}

1. Japp, A.G.; Gulati, A.; Cook, S.A.; Cowie, M.R.; Prasad, S.K. The Diagnosis and Evaluation of Dilated Cardiomyopathy. J. Am. Coll. Cardiol. 2016, 67, 2996-3010. [CrossRef] [PubMed]

2. McNally, E.M.; Mestroni, L. Dilated Cardiomyopathy: Genetic Determinants and Mechanisms. Circ. Res. 2017, 121, 731-748. [CrossRef] [PubMed]

3. Weintraub, R.G.; Semsarian, C.; Macdonald, P. Dilated cardiomyopathy. Lancet 2017, 390, 400-414. [CrossRef]

4. Benjamin, E.J.; Muntner, P.; Alonso, A.; Bittencourt, M.S.; Callaway, C.W.; Carson, A.P.; Chamberlain, A.M.; Chang, A.R.; Cheng, S.; Das, S.R.; et al. Heart Disease and Stroke Statistics-2019 Update: A Report From the American Heart Association. Circulation 2019, 139, e56-e528. [CrossRef] [PubMed]

5. Bozkurt, B.; Colvin, M.; Cook, J.; Cooper, L.T.; Deswal, A.; Fonarow, G.C.; Francis, G.S.; Lenihan, D.; Lewis, E.F.; McNamara, D.M.; et al. Current Diagnostic and Treatment Strategies for Specific Dilated Cardiomyopathies: A Scientific Statement from the American Heart Association. Circulation 2016, 134, e579-e646. [CrossRef] [PubMed]

6. Eisenberg, E.; Di Palo, K.E.; Pina, I.L. Sex differences in heart failure. Clin. Cardiol. 2018, 41, $211-216$. [CrossRef] [PubMed]

7. Yancy, C.W.; Jessup, M.; Bozkurt, B.; Butler, J.; Casey, D.E., Jr.; Drazner, M.H.; Fonarow, G.C.; Geraci, S.A.; Horwich, T.; Januzzi, J.L.; et al. 2013 ACCF/AHA guideline for the management of heart failure: Executive summary: A report of the American College of Cardiology Foundation/American Heart Association Task Force on practice guidelines. Circulation 2013, 128, 1810-1852. [CrossRef] [PubMed]

8. Ware, L.B.; Matthay, M.A. Clinical practice. Acute pulmonary edema. N. Engl. J. Med. 2005, 353, $2788-2796$. [CrossRef]

9. Dzau, V.J.; Colucci, W.S.; Hollenberg, N.K.; Williams, G.H. Relation of the renin-angiotensin-aldosterone system to clinical state in congestive heart failure. Circulation 1981, 63, 645-651. [CrossRef]

10. Levine, T.B.; Francis, G.S.; Goldsmith, S.R.; Simon, A.B.; Cohn, J.N. Activity of the sympathetic nervous system and renin-angiotensin system assessed by plasma hormone levels and their relation to hemodynamic abnormalities in congestive heart failure. Am. J. Cardiol. 1982, 49, 1659-1666. [CrossRef]

11. Schrier, R.W.; Abraham, W.T. Hormones and hemodynamics in heart failure. N. Engl. J. Med. 1999, 341, 577-585. [CrossRef]

12. Zucker, I.H.; Xiao, L.; Haack, K.K. The central renin-angiotensin system and sympathetic nerve activity in chronic heart failure. Clin. Sci. (Lond.) 2014, 126, 695-706. [CrossRef] [PubMed]

13. Hartupee, J.; Mann, D.L. Neurohormonal activation in heart failure with reduced ejection fraction. Nat. Rev. Cardiol. 2017, 14, 30-38. [CrossRef]

14. Triposkiadis, F.; Karayannis, G.; Giamouzis, G.; Skoularigis, J.; Louridas, G.; Butler, J. The sympathetic nervous system in heart failure physiology, pathophysiology, and clinical implications. J. Am. Coll. Cardiol. 2009, 54, 1747-1762. [CrossRef] [PubMed]

15. Armstrong, P.W.; Stopps, T.P.; Ford, S.E.; de Bold, A.J. Rapid ventricular pacing in the dog: Pathophysiologic studies of heart failure. Circulation 1986, 74, 1075-1084. [CrossRef] [PubMed] 
16. Francis, G.S.; Benedict, C.; Johnstone, D.E.; Kirlin, P.C.; Nicklas, J.; Liang, C.S.; Kubo, S.H.; Rudin-Toretsky, E.; Yusuf, S. Comparison of neuroendocrine activation in patients with left ventricular dysfunction with and without congestive heart failure. A substudy of the Studies of Left Ventricular Dysfunction (SOLVD). Circulation 1990, 82, 1724-1729. [CrossRef] [PubMed]

17. Kalra, P.R.; Anker, S.D.; Coats, A.J. Water and sodium regulation in chronic heart failure: The role of natriuretic peptides and vasopressin. Cardiovasc. Res. 2001, 51, 495-509. [CrossRef]

18. Gladysheva, I.P.; Wang, D.; McNamee, R.A.; Houng, A.K.; Mohamad, A.A.; Fan, T.M.; Reed, G.L. Corin overexpression improves cardiac function, heart failure, and survival in mice with dilated cardiomyopathy. Hypertension 2013, 61, 327-332. [CrossRef]

19. Zhou, Y.; Wu, Q. Corin in natriuretic peptide processing and hypertension. Curr. Hypertens. Rep. 2014, 16, 415. [CrossRef]

20. Bayes-Genis, A.; Barallat, J.; Galan, A.; de Antonio, M.; Domingo, M.; Zamora, E.; Urrutia, A.; Lupon, J. Soluble neprilysin is predictive of cardiovascular death and heart failure hospitalization in heart failure patients. J. Am. Coll. Cardiol. 2015, 65, 657-665. [CrossRef]

21. Huntley, B.K.; Sandberg, S.M.; Heublein, D.M.; Sangaralingham, S.J.; Burnett, J.C., Jr.; Ichiki, T. Pro-B-type natriuretic peptide-1-108 processing and degradation in human heart failure. Circ. Heart Fail. 2015, 8, 89-97. [CrossRef] [PubMed]

22. Burnett, J.C., Jr.; Kao, P.C.; Hu, D.C.; Heser, D.W.; Heublein, D.; Granger, J.P.; Opgenorth, T.J.; Reeder, G.S. Atrial natriuretic peptide elevation in congestive heart failure in the human. Science 1986, 231, 1145-1147. [CrossRef] [PubMed]

23. Ibebuogu, U.N.; Gladysheva, I.P.; Houng, A.K.; Reed, G.L. Decompensated heart failure is associated with reduced corin levels and decreased cleavage of pro-atrial natriuretic peptide. Circ. Heart Fail. 2011, 4, 114-120. [CrossRef]

24. Dries, D.L. Process matters: Emerging concepts underlying impaired natriuretic peptide system function in heart failure. Circ. Heart Fail. 2011, 4, 107-110. [CrossRef] [PubMed]

25. Zaidi, S.S.; Ward, R.D.; Ramanathan, K.; Yu, X.; Gladysheva, I.P.; Reed, G.L. Possible Enzymatic Downregulation of the Natriuretic Peptide System in Patients with Reduced Systolic Function and Heart Failure: A Pilot Study. Biomed. Res. Int. 2018, 2018, 6. [CrossRef] [PubMed]

26. George, J.; Struthers, A.D.; Lang, C.C. Modulation of the renin-angiotensin-aldosterone system in heart failure. Curr. Atheroscler. Rep. 2014, 16, 403. [CrossRef] [PubMed]

27. Skeggs, L.T., Jr.; Kahn, J.R.; Lentz, K.; Shumway, N.P. The preparation, purification, and amino acid sequence of a polypeptide renin substrate. J. Exp. Med. 1957, 106, 439-453. [CrossRef]

28. Group, C.T.S. Effects of enalapril on mortality in severe congestive heart failure. Results of the Cooperative North Scandinavian Enalapril Survival Study (CONSENSUS). N. Engl. J. Med. 1987, 316, 1429-1435. [CrossRef]

29. Investigators, S.; Yusuf, S.; Pitt, B.; Davis, C.E.; Hood, W.B., Jr.; Cohn, J.N. Effect of enalapril on mortality and the development of heart failure in asymptomatic patients with reduced left ventricular ejection fractions. $N$. Engl. J. Med. 1992, 327, 685-691. [CrossRef]

30. Packer, M.; Poole-Wilson, P.A.; Armstrong, P.W.; Cleland, J.G.; Horowitz, J.D.; Massie, B.M.; Ryden, L.; Thygesen, K.; Uretsky, B.F. Comparative effects of low and high doses of the angiotensin-converting enzyme inhibitor, lisinopril, on morbidity and mortality in chronic heart failure. ATLAS Study Group. Circulation 1999, 100, 2312-2318. [CrossRef]

31. Pitt, B.; Zannad, F.; Remme, W.J.; Cody, R.; Castaigne, A.; Perez, A.; Palensky, J.; Wittes, J. The effect of spironolactone on morbidity and mortality in patients with severe heart failure. Randomized Aldactone Evaluation Study Investigators. N. Engl. J. Med. 1999, 341, 709-717. [CrossRef] [PubMed]

32. Pitt, B.; Poole-Wilson, P.A.; Segal, R.; Martinez, F.A.; Dickstein, K.; Camm, A.J.; Konstam, M.A.; Riegger, G.; Klinger, G.H.; Neaton, J.; et al. Effect of losartan compared with captopril on mortality in patients with symptomatic heart failure: Randomised trial-the Losartan Heart Failure Survival Study ELITE II. Lancet 2000, 355, 1582-1587. [CrossRef]

33. Flather, M.D.; Yusuf, S.; Kober, L.; Pfeffer, M.; Hall, A.; Murray, G.; Torp-Pedersen, C.; Ball, S.; Pogue, J.; Moye, L.; et al. Long-term ACE-inhibitor therapy in patients with heart failure or left-ventricular dysfunction: A systematic overview of data from individual patients. ACE-Inhibitor Myocardial Infarction Collaborative Group. Lancet 2000, 355, 1575-1581. [CrossRef] 
34. Cohn, J.N.; Tognoni, G.; Valsartan Heart Failure Trial Investigators. A randomized trial of the angiotensin-receptor blocker valsartan in chronic heart failure. N. Engl. J. Med. 2001, 345, 1667-1675. [CrossRef] [PubMed]

35. Granger, C.B.; McMurray, J.J.; Yusuf, S.; Held, P.; Michelson, E.L.; Olofsson, B.; Ostergren, J.; Pfeffer, M.A.; Swedberg, K.; CHARM Investigators and Committees. Effects of candesartan in patients with chronic heart failure and reduced left-ventricular systolic function intolerant to angiotensin-converting-enzyme inhibitors: The CHARM-Alternative trial. Lancet 2003, 362, 772-776. [CrossRef]

36. Pfeffer, M.A.; Swedberg, K.; Granger, C.B.; Held, P.; McMurray, J.J.; Michelson, E.L.; Olofsson, B.; Ostergren, J.; Yusuf, S.; Pocock, S.; et al. Effects of candesartan on mortality and morbidity in patients with chronic heart failure: The CHARM-Overall programme. Lancet 2003, 362, 759-766. [CrossRef]

37. Pitt, B.; Remme, W.; Zannad, F.; Neaton, J.; Martinez, F.; Roniker, B.; Bittman, R.; Hurley, S.; Kleiman, J.; Gatlin, M.; et al. Survival Study, I. Eplerenone, a selective aldosterone blocker, in patients with left ventricular dysfunction after myocardial infarction. N. Engl. J. Med. 2003, 348, 1309-1321. [CrossRef] [PubMed]

38. Yancy, C.W.; Jessup, M.; Bozkurt, B.; Butler, J.; Casey, D.E., Jr.; Colvin, M.M.; Drazner, M.H.; Filippatos, G.S.; Fonarow, G.C.; Givertz, M.M.; et al. 2017 ACC/AHA/HFSA Focused Update of the 2013 ACCF/AHA Guideline for the Management of Heart Failure: A Report of the American College of Cardiology/American Heart Association Task Force on Clinical Practice Guidelines and the Heart Failure Society of America. Circulation 2017, 136, e137-e161. [CrossRef]

39. Orsborne, C.; Chaggar, P.S.; Shaw, S.M.; Williams, S.G. The renin-angiotensin-aldosterone system in heart failure for the non-specialist: The past, the present and the future. Postgrad. Med. J. 2017, 93, 29-37. [CrossRef]

40. Gheorghiade, M.; Bohm, M.; Greene, S.J.; Fonarow, G.C.; Lewis, E.F.; Zannad, F.; Solomon, S.D.; Baschiera, F.; Botha, J.; Hua, T.A.; et al. Effect of aliskiren on postdischarge mortality and heart failure readmissions among patients hospitalized for heart failure: The ASTRONAUT randomized trial. JAMA 2013, 309, 1125-1135. [CrossRef]

41. McMurray, J.J.; Krum, H.; Abraham, W.T.; Dickstein, K.; Kober, L.V.; Desai, A.S.; Solomon, S.D.; Greenlaw, N.; Ali, M.A.; Chiang, Y.; et al. Aliskiren, Enalapril, or Aliskiren and Enalapril in Heart Failure. N. Engl. J. Med. 2016, 374, 1521-1532. [CrossRef] [PubMed]

42. Liu, H.; Luo, H.; Wang, S.; Zhang, C.; Hao, J.; Gao, C. Aliskiren for heart failure: A systematic review and meta-analysis of randomized controlled trials. Oncotarget 2017, 8, 88189-88198. [CrossRef] [PubMed]

43. Wollert, K.C.; Drexler, H. The renin-angiotensin system and experimental heart failure. Cardiovasc. Res. 1999, 43, 838-849. [CrossRef]

44. Sparks, M.A.; Crowley, S.D.; Gurley, S.B.; Mirotsou, M.; Coffman, T.M. Classical Renin-Angiotensin system in kidney physiology. Compr. Physiol. 2014, 4, 1201-1228. [CrossRef] [PubMed]

45. Von Lueder, T.G.; Sangaralingham, S.J.; Wang, B.H.; Kompa, A.R.; Atar, D.; Burnett, J.C., Jr.; Krum, H. Renin-angiotensin blockade combined with natriuretic peptide system augmentation: Novel therapeutic concepts to combat heart failure. Circ. Heart Fail. 2013, 6, 594-605. [CrossRef]

46. Tigerstedt, R.B.P.G. Niere und Kreislauf. Skand. Arch. Physiol. 1898, 8, 223-271. [CrossRef]

47. Sielecki, A.R.; Hayakawa, K.; Fujinaga, M.; Murphy, M.E.; Fraser, M.; Muir, A.K.; Carilli, C.T.; Lewicki, J.A.; Baxter, J.D.; James, M.N. Structure of recombinant human renin, a target for cardiovascular-active drugs, at 2.5 A resolution. Science 1989, 243, 1346-1351. [CrossRef]

48. Muller, D.N.; Luft, F.C. Direct renin inhibition with aliskiren in hypertension and target organ damage. Clin. J. Am. Soc. Nephrol. 2006, 1, 221-228. [CrossRef]

49. Gould, A.B.; Green, D. Kinetics of the human renin and human substrate reaction. Cardiovasc. Res. 1971, 5, 86-89. [CrossRef]

50. Cleland, S.J.; Reid, J.L. The renin-angiotensin system and the heart: A historical review. Heart 1996, 76 (Suppl. 3), 7-12. [CrossRef]

51. Weber, K.T. Aldosterone in congestive heart failure. N. Engl. J. Med. 2001, 345, 1689-1697. [CrossRef] [PubMed]

52. Ferrario, C.M.; Chappell, M.C.; Tallant, E.A.; Brosnihan, K.B.; Diz, D.I. Counterregulatory actions of angiotensin-(1-7). Hypertension 1997, 30 (3 Pt 2), 535-541. [CrossRef]

53. Santos, R.A.; Campagnole-Santos, M.J.; Andrade, S.P. Angiotensin-(1-7): An update. Regul. Pept. 2000, 91, 45-62. [CrossRef] 
54. Tallant, E.A.; Ferrario, C.M.; Gallagher, P.E. Angiotensin-(1-7) inhibits growth of cardiac myocytes through activation of the mas receptor. Am. J. Physiol. Heart Circ. Physiol. 2005, 289, H1560-H1566. [CrossRef] [PubMed]

55. Fyhrquist, F.; Saijonmaa, O. Renin-angiotensin system revisited. J. Intern. Med. 2008, 264, 224-236. [CrossRef] [PubMed]

56. Zhou, X.; Shang, D.; Zhang, T.; Li, L.; Zhou, T.; Lu, W. Modeling of angiotensin II-angiotensin-(1-7) counterbalance in disease progression in spontaneously hypertensive rats treated with/without perindopril. Pharm. Res. 2012, 66, 177-184. [CrossRef]

57. Santos, R.A.; Ferreira, A.J.; Verano-Braga, T.; Bader, M. Angiotensin-converting enzyme 2, angiotensin-(1-7) and Mas: New players of the renin-angiotensin system. J. Endocrinol. 2013, 216, R1-R17. [CrossRef]

58. Gironacci, M.M.; Adamo, H.P.; Corradi, G.; Santos, R.A.; Ortiz, P.; Carretero, O.A. Angiotensin (1-7) induces MAS receptor internalization. Hypertension 2011, 58, 176-181. [CrossRef]

59. Santos, R.A.; Simoes e Silva, A.C.; Maric, C.; Silva, D.M.; Machado, R.P.; de Buhr, I.; Heringer-Walther, S.; Pinheiro, S.V.; Lopes, M.T.; Bader, M.; et al. Angiotensin-(1-7) is an endogenous ligand for the G protein-coupled receptor Mas. Proc. Natl. Acad. Sci. USA 2003, 100, 8258-8263. [CrossRef]

60. Carey, R.M. Update on the role of the AT2 receptor. Curr. Opin. Nephrol. Hypertens. 2005, 14, 67-71. [CrossRef]

61. Carey, R.M. AT2 Receptors: Potential Therapeutic Targets for Hypertension. Am. J. Hypertens. 2017, 30, 339-347. [CrossRef] [PubMed]

62. Booz, G.W. Cardiac angiotensin AT2 receptor: What exactly does it do? Hypertension 2004, 43, 1162-1163. [CrossRef] [PubMed]

63. Jones, E.S.; Vinh, A.; McCarthy, C.A.; Gaspari, T.A.; Widdop, R.E. AT2 receptors: Functional relevance in cardiovascular disease. Pharmacol. Ther. 2008, 120, 292-316. [CrossRef] [PubMed]

64. Campbell, D.J. Renin inhibitors-Mechanisms of action. Aust. Prescr. 2009, 32, 132-135. [CrossRef]

65. Opie, L.H.; Sack, M.N. Enhanced angiotensin II activity in heart failure: Reevaluation of the counterregulatory hypothesis of receptor subtypes. Circ. Res. 2001, 88, 654-658. [CrossRef] [PubMed]

66. Levy, B.I. Can angiotensin II type 2 receptors have deleterious effects in cardiovascular disease? Implications for therapeutic blockade of the renin-angiotensin system. Circulation 2004, 109, 8-13. [CrossRef]

67. Lemarie, C.A.; Schiffrin, E.L. The angiotensin II type 2 receptor in cardiovascular disease. J. Renin Angiotensin Aldosterone Syst. 2010, 11, 19-31. [CrossRef] [PubMed]

68. Avila, M.D.; Morgan, J.P.; Yan, X. Genetically modified mouse models used for studying the role of the AT2 receptor in cardiac hypertrophy and heart failure. J. Biomed. Biotechnol. 2011, 2011, 141039. [CrossRef]

69. Hobart, P.M.; Fogliano, M.; O'Connor, B.A.; Schaefer, I.M.; Chirgwin, J.M. Human renin gene: Structure and sequence analysis. Proc. Natl. Acad. Sci. USA 1984, 81, 5026-5030. [CrossRef]

70. Khan, A.R.; James, M.N. Molecular mechanisms for the conversion of zymogens to active proteolytic enzymes. Protein Sci. 1998, 7, 815-836. [CrossRef]

71. Prieto-Carrasquero, M.C.; Harrison-Bernard, L.M.; Kobori, H.; Ozawa, Y.; Hering-Smith, K.S.; Hamm, L.L.; Navar, L.G. Enhancement of collecting duct renin in angiotensin II-dependent hypertensive rats. Hypertension 2004, 44, 223-229. [CrossRef] [PubMed]

72. Krop, M.; Lu, X.; Danser, A.H.; Meima, M.E. The (pro)renin receptor. A decade of research: What have we learned? Pflug. Arch. 2013, 465, 87-97. [CrossRef] [PubMed]

73. Castrop, H.; Hocherl, K.; Kurtz, A.; Schweda, F.; Todorov, V.; Wagner, C. Physiology of kidney renin. Physiol. Rev. 2010, 90, 607-673. [CrossRef] [PubMed]

74. Kurtz, A. Control of renin synthesis and secretion. Am. J. Hypertens. 2012, 25, 839-847. [CrossRef] [PubMed]

75. Heger, J.; Schluter, K.D. Renin and the IGFII/M6P receptor system in cardiac biology. Sci. World J. 2013, 2013, 260298. [CrossRef] [PubMed]

76. Grunberger, C.; Obermayer, B.; Klar, J.; Kurtz, A.; Schweda, F. The calcium paradoxon of renin release: Calcium suppresses renin exocytosis by inhibition of calcium-dependent adenylate cyclases AC5 and AC6. Circ. Res. 2006, 99, 1197-1206. [CrossRef] [PubMed]

77. Beierwaltes, W.H. The role of calcium in the regulation of renin secretion. Am. J. Physiol. Ren. Physiol. 2010, 298, F1-F11. [CrossRef] 
78. Kurtz, A.; Della Bruna, R.; Pfeilschifter, J.; Taugner, R.; Bauer, C. Atrial natriuretic peptide inhibits renin release from juxtaglomerular cells by a cGMP-mediated process. Proc. Natl. Acad. Sci. USA 1986, 83, 4769-4773. [CrossRef] [PubMed]

79. Gambaryan, S.; Wagner, C.; Smolenski, A.; Walter, U.; Poller, W.; Haase, W.; Kurtz, A.; Lohmann, S.M. Endogenous or overexpressed cGMP-dependent protein kinases inhibit cAMP-dependent renin release from rat isolated perfused kidney, microdissected glomeruli, and isolated juxtaglomerular cells. Proc. Natl. Acad. Sci. USA 1998, 95, 9003-9008. [CrossRef]

80. Wagner, C.; Pfeifer, A.; Ruth, P.; Hofmann, F.; Kurtz, A. Role of cGMP-kinase II in the control of renin secretion and renin expression. J. Clin. Investig. 1998, 102, 1576-1582. [CrossRef]

81. Fournier, D.; Luft, F.C.; Bader, M.; Ganten, D.; Andrade-Navarro, M.A. Emergence and evolution of the renin-angiotensin-aldosterone system. J. Mol. Med. (Berl.) 2012, 90, 495-508. [CrossRef] [PubMed]

82. Brown, M.J. Renin: Friend or foe? Heart 2007, 93, 1026-1033. [CrossRef] [PubMed]

83. Lorenz, J.N.; Weihprecht, H.; Schnermann, J.; Skott, O.; Briggs, J.P. Renin release from isolated juxtaglomerular apparatus depends on macula densa chloride transport. Am. J. Physiol. 1991, 260, F486-F493. [CrossRef] [PubMed]

84. Bock, H.A.; Hermle, M.; Brunner, F.P.; Thiel, G. Pressure dependent modulation of renin release in isolated perfused glomeruli. Kidney Int. 1992, 41, 275-280. [CrossRef] [PubMed]

85. Carey, R.M.; McGrath, H.E.; Pentz, E.S.; Gomez, R.A.; Barrett, P.Q. Biomechanical coupling in renin-releasing cells. J. Clin. Investig. 1997, 100, 1566-1574. [CrossRef] [PubMed]

86. Tatemichi, S.R.; Osmond, D.H. Factor XII in endogenous activation of inactive renin. Lancet 1978, 1, 1313. [CrossRef]

87. Sealey, J.E.; Atlas, S.A.; Laragh, J.H.; Silverberg, M.; Kaplan, A.P. Initiation of plasma prorenin activation by Hageman factor-dependent conversion of plasma prekallikrein to kallikrein. Proc. Natl. Acad. Sci. USA 1979, 76, 5914-5918. [CrossRef] [PubMed]

88. Rumpf, K.W.; Becker, K.; Kreusch, U.; Schmidt, S.; Vetter, R.; Scheler, F. Evidence for a role of plasma kallikrein in the activation of prorenin. Nature 1980, 283, 482-483. [CrossRef] [PubMed]

89. Mantero, F.; Fallo, F.; Patrassi, G.; Sarandria, A.; Pedini, F.; Girolami, A. Effect of Captoril on Inactive Renin and Contact Phase of Coagulation System. Clin. Exp. Hypertens. 1982, 4, 2425-2434. [CrossRef]

90. Patrassi, G.M.; Fallo, F.; Martinelli, S.; Mantero, F.; Boeri, G.; Girolami, A. The contact phase of blood coagulation and renin activation in essential hypertension before and after captopril. Eur. Heart J. 1984, 5, 561-567. [CrossRef]

91. Reudelhuber, T.L.; Ramla, D.; Chiu, L.; Mercure, C.; Seidah, N.G. Proteolytic processing of human prorenin in renal and non-renal tissues. Kidney Int. 1994, 46, 1522-1524. [CrossRef] [PubMed]

92. Derkx, F.H.; Schalekamp, M.P.; Schalekamp, M.A. Two-step prorenin-renin conversion. Isolation of an intermediary form of activated prorenin. J. Biol. Chem. 1987, 262, 2472-2477. [PubMed]

93. Leckie, E.J. The reversible activation of inactive renin in human plasma: Role of acid and of plasma kallikrein and plasmin. Clin. Exp. Hypertens. A 1982, 4, 2133-2147. [CrossRef] [PubMed]

94. Mercure, C.; Lacombe, M.J.; Khazaie, K.; Reudelhuber, T.L. Cathepsin B is not the processing enzyme for mouse prorenin. Am. J. Physiol. Regul. Integr. Comp. Physiol. 2010, 298, R1212-R1216. [CrossRef] [PubMed]

95. Nguyen, G.; Delarue, F.; Burckle, C.; Bouzhir, L.; Giller, T.; Sraer, J.D. Pivotal role of the renin/prorenin receptor in angiotensin II production and cellular responses to renin. J. Clin. Investig. 2002, 109, 1417-1427. [CrossRef] [PubMed]

96. Pratt, R.E.; Carleton, J.E.; Richie, J.P.; Heusser, C.; Dzau, V.J. Human renin biosynthesis and secretion in normal and ischemic kidneys. Proc. Natl. Acad. Sci. USA 1987, 84, 7837-7840. [CrossRef] [PubMed]

97. Batenburg, W.W.; Danser, A.H.J. Prorenin and the (pro)renin receptor: Binding kinetics, signalling and interaction with aliskiren. J. Renin-Angiotensin-Aldosterone Syst. 2008, 9, 181-184. [CrossRef] [PubMed]

98. Nguyen, G. Renin and prorenin receptor in hypertension: what's new? Curr. Hypertens. Rep. 2011, 13, 79-85. [CrossRef]

99. Schroten, N.F.; Gaillard, C.A.; van Veldhuisen, D.J.; Szymanski, M.K.; Hillege, H.L.; de Boer, R.A. New roles for renin and prorenin in heart failure and cardiorenal crosstalk. Heart Fail. Rev. 2012, 17, 191-201. [CrossRef]

100. Binger, K.J.; Muller, D.N. Autophagy and the (Pro)renin Receptor. Front. Endocrinol. (Lausanne) 2013, 4, 155. [CrossRef] 
101. Danser, A.H.; van Kats, J.P.; Admiraal, P.J.; Derkx, F.H.; Lamers, J.M.; Verdouw, P.D.; Saxena, P.R.; Schalekamp, M.A. Cardiac renin and angiotensins. Uptake from plasma versus in situ synthesis. Hypertension 1994, 24, 37-48. [CrossRef] [PubMed]

102. Lavoie, J.L.; Sigmund, C.D. Minireview: Overview of the renin-angiotensin system-an endocrine and paracrine system. Endocrinology 2003, 144, 2179-2183. [CrossRef] [PubMed]

103. Danser, A.H.; Deinum, J. Renin, prorenin and the putative (pro)renin receptor. J. Renin Angiotensin Aldosterone Syst. 2005, 6, 163-165. [CrossRef] [PubMed]

104. Paul, M.; Poyan Mehr, A.; Kreutz, R. Physiology of local renin-angiotensin systems. Physiol. Rev. 2006, 86, 747-803. [CrossRef] [PubMed]

105. Nabi, A.H.; Kageshima, A.; Uddin, M.N.; Nakagawa, T.; Park, E.Y.; Suzuki, F. Binding properties of rat prorenin and renin to the recombinant rat renin/prorenin receptor prepared by a baculovirus expression system. Int J. Mol. Med. 2006, 18, 483-488. [CrossRef] [PubMed]

106. Sawa, H.; Tokuchi, F.; Mochizuki, N.; Endo, Y.; Furuta, Y.; Shinohara, T.; Takada, A.; Kawaguchi, H.; Yasuda, H.; Nagashima, K. Expression of the angiotensinogen gene and localization of its protein in the human heart. Circulation 1992, 86, 138-146. [CrossRef] [PubMed]

107. Iwai, N.; Shimoike, H.; Kinoshita, M. Cardiac renin-angiotensin system in the hypertrophied heart. Circulation 1995, 92, 2690-2696. [CrossRef] [PubMed]

108. Kleiger, R.E.; Miller, J.P.; Bigger, J.T., Jr.; Moss, A.J. Decreased heart rate variability and its association with increased mortality after acute myocardial infarction. Am. J. Cardiol. 1987, 59, 256-262. [CrossRef]

109. Van Kesteren, C.A.; Danser, A.H.; Derkx, F.H.; Dekkers, D.H.; Lamers, J.M.; Saxena, P.R.; Schalekamp, M.A. Mannose 6-phosphate receptor-mediated internalization and activation of prorenin by cardiac cells. Hypertension 1997, 30, 1389-1396. [CrossRef]

110. Ichihara, A.; Hayashi, M.; Kaneshiro, Y.; Suzuki, F.; Nakagawa, T.; Tada, Y.; Koura, Y.; Nishiyama, A.; Okada, H.; Uddin, M.N.; et al. Inhibition of diabetic nephropathy by a decoy peptide corresponding to the "handle" region for nonproteolytic activation of prorenin. J. Clin. Investig. 2004, 114, 1128-1135. [CrossRef]

111. Ichihara, A.; Kaneshiro, Y.; Takemitsu, T.; Sakoda, M.; Suzuki, F.; Nakagawa, T.; Nishiyama, A.; Inagami, T.; Hayashi, M. Nonproteolytic activation of prorenin contributes to development of cardiac fibrosis in genetic hypertension. Hypertension 2006, 47, 894-900. [CrossRef] [PubMed]

112. Danser, A.H. Prorenin: Back into the arena. Hypertension 2006, 47, 824-826. [CrossRef] [PubMed]

113. Oliver, J.A. Receptor-mediated actions of renin and prorenin. Kidney Int. 2006, 69, 13-15. [CrossRef] [PubMed]

114. Nguyen, G. Renin/prorenin receptors. Kidney Int. 2006, 69, 1503-1506. [CrossRef] [PubMed]

115. Nguyen, G.; Danser, A.H. The (pro)renin receptor: Therapeutic consequences. Expert Opin. Investig. Drugs 2006, 15, 1131-1135. [CrossRef] [PubMed]

116. Ichihara, A.; Suzuki, F.; Nakagawa, T.; Kaneshiro, Y.; Takemitsu, T.; Sakoda, M.; Nabi, A.H.; Nishiyama, A.; Sugaya, T.; Hayashi, M.; et al. Prorenin receptor blockade inhibits development of glomerulosclerosis in diabetic angiotensin II type 1a receptor-deficient mice. J. Am. Soc. Nephrol. 2006, 17, 1950-1961. [CrossRef] [PubMed]

117. Huang, Y.; Wongamorntham, S.; Kasting, J.; McQuillan, D.; Owens, R.T.; Yu, L.; Noble, N.A.; Border, W. Renin increases mesangial cell transforming growth factor-beta1 and matrix proteins through receptor-mediated, angiotensin II-independent mechanisms. Kidney Int. 2006, 69, 105-113. [CrossRef]

118. Cousin, C.; Bracquart, D.; Contrepas, A.; Corvol, P.; Muller, L.; Nguyen, G. Soluble form of the (pro)renin receptor generated by intracellular cleavage by furin is secreted in plasma. Hypertension 2009, 53, 1077-1082. [CrossRef]

119. Yoshikawa, A.; Aizaki, Y.; Kusano, K.; Kishi, F.; Susumu, T.; Iida, S.; Ishiura, S.; Nishimura, S.; Shichiri, M.; Senbonmatsu, T. The (pro)renin receptor is cleaved by ADAM19 in the Golgi leading to its secretion into extracellular space. Hypertens. Res. 2011, 34, 599-605. [CrossRef]

120. Ohashi, N.; Isobe, S.; Ishigaki, S.; Suzuki, T.; Iwakura, T.; Ono, M.; Fujikura, T.; Tsuji, T.; Otsuka, A.; Ishii, Y.; et al. Plasma Soluble (Pro)renin Receptor Reflects Renal Damage. PLoS ONE 2016, 11, e0156165. [CrossRef]

121. Gong, L.; Zhang, S.; Li, L.; Gao, X.; Wang, D.; Wu, D.; Wang, K.; Liu, Y. Elevated plasma soluble (pro)renin receptor levels are associated with left ventricular remodeling and renal function in chronic heart failure patients with reduced ejection fraction. Peptides 2019, 111, 152-157. [CrossRef] [PubMed] 
122. Danser, A.H. The increase in renin during renin inhibition: Does it result in harmful effects by the (pro)renin receptor? Hypertens. Res. 2010, 33, 4-10. [CrossRef] [PubMed]

123. Trepiccione, F.; Gerber, S.D.; Grahammer, F.; Lopez-Cayuqueo, K.I.; Baudrie, V.; Paunescu, T.G.; Capen, D.E.; Picard, N.; Alexander, R.T.; Huber, T.B.; et al. Renal Atp6ap2/(Pro)renin Receptor Is Required for Normal Vacuolar H+-ATPase Function but Not for the Renin-Angiotensin System. J. Am. Soc. Nephrol. 2016, 27, 3320-3330. [CrossRef] [PubMed]

124. Van den Eijnden, M.M.; Saris, J.J.; de Bruin, R.J.; de Wit, E.; Sluiter, W.; Reudelhuber, T.L.; Schalekamp, M.A.; Derkx, F.H.; Danser, A.H. Prorenin accumulation and activation in human endothelial cells: Importance of mannose 6-phosphate receptors. Arter. Thromb. Vasc. Biol. 2001, 21, 911-916. [CrossRef]

125. Nguyen, G.; Contrepas, A. The (pro)renin receptors. J. Mol. Med. (Berl.) 2008, 86, 643-646. [CrossRef] [PubMed]

126. Saris, J.J.; Derkx, F.H.; De Bruin, R.J.; Dekkers, D.H.; Lamers, J.M.; Saxena, P.R.; Schalekamp, M.A.; Jan Danser, A.H. High-affinity prorenin binding to cardiac man-6-P/IGF-II receptors precedes proteolytic activation to renin. Am. J. Physiol. Heart Circ. Physiol. 2001, 280, H1706-H1715. [CrossRef] [PubMed]

127. Batenburg, W.W.; Danser, A.H. (Pro)renin and its receptors: Pathophysiological implications. Clin. Sci. (Lond.) 2012, 123, 121-133. [CrossRef] [PubMed]

128. Lee, S.D.; Chu, C.H.; Huang, E.J.; Lu, M.C.; Liu, J.Y.; Liu, C.J.; Hsu, H.H.; Lin, J.A.; Kuo, W.W.; Huang, C.Y. Roles of insulin-like growth factor II in cardiomyoblast apoptosis and in hypertensive rat heart with abdominal aorta ligation. Am. J. Physiol. Endocrinol. Metab. 2006, 291, E306-E314. [CrossRef]

129. Huang, C.Y.; Kuo, W.W.; Yeh, Y.L.; Ho, T.J.; Lin, J.Y.; Lin, D.Y.; Chu, C.H.; Tsai, F.J.; Tsai, C.H.; Huang, C.Y. ANG II promotes IGF-IIR expression and cardiomyocyte apoptosis by inhibiting HSF1 via JNK activation and SIRT1 degradation. Cell Death Differ. 2014, 21, 1262-1274. [CrossRef]

130. Huang, C.Y.; Kuo, C.H.; Pai, P.Y.; Ho, T.J.; Lin, Y.M.; Chen, R.J.; Tsai, F.J.; Vijaya Padma, V.; Kuo, W.W.; Huang, C.Y. Inhibition of HSF2 SUMOylation via MEL18 upregulates IGF-IIR and leads to hypertension-induced cardiac hypertrophy. Int. J. Cardiol. 2018, 257, 283-290. [CrossRef]

131. Huang, C.Y.; Lee, F.L.; Peng, S.F.; Lin, K.H.; Chen, R.J.; Ho, T.J.; Tsai, F.J.; Padma, V.V.; Kuo, W.W.; Huang, C.Y. HSF1 phosphorylation by ERK/GSK3 suppresses RNF126 to sustain IGF-IIR expression for hypertension-induced cardiomyocyte hypertrophy. J. Cell Physiol. 2018, 233, 979-989. [CrossRef] [PubMed]

132. Wei, Y.; Li, J.; Huang, J.; Zhang, X.; Zhao, H.; Cui, C.; Li, Y.; Hu, S. Elevation of IGF-2 receptor and the possible underlying implications in end-stage heart failure patients before and after heart transplantation. J. Cell Mol. Med. 2012, 16, 1038-1046. [CrossRef] [PubMed]

133. Hinrichs, S.; Heger, J.; Schreckenberg, R.; Wenzel, S.; Euler, G.; Arens, C.; Bader, M.; Rosenkranz, S.; Caglayan, E.; Schluter, K.D. Controlling cardiomyocyte length: The role of renin and PPAR-\{gamma\}. Cardiovasc. Res. 2011, 89, 344-352. [CrossRef] [PubMed]

134. El-Shewy, H.M.; Lee, M.H.; Obeid, L.M.; Jaffa, A.A.; Luttrell, L.M. The insulin-like growth factor type 1 and insulin-like growth factor type 2/mannose-6-phosphate receptors independently regulate ERK1/2 activity in HEK293 cells. J. Biol. Chem. 2007, 282, 26150-26157. [CrossRef] [PubMed]

135. Todorov, V.T.; Desch, M.; Schmitt-Nilson, N.; Todorova, A.; Kurtz, A. Peroxisome proliferator-activated receptor-gamma is involved in the control of renin gene expression. Hypertension 2007, 50, 939-944. [CrossRef] [PubMed]

136. Wylie, A.A.; Pulford, D.J.; McVie-Wylie, A.J.; Waterland, R.A.; Evans, H.K.; Chen, Y.T.; Nolan, C.M.; Orton, T.C.; Jirtle, R.L. Tissue-specific inactivation of murine M6P/IGF2R. Am. J. Pathol. 2003, 162, 321-328. [CrossRef]

137. Muller, D.N.; Derer, W.; Dechend, R. Aliskiren-mode of action and preclinical data. J. Mol. Med. (Berl.) 2008, 86, 659-662. [CrossRef]

138. Teisman, A.C.; van Veldhuisen, D.J.; Boomsma, F.; de Kam, P.J.; Tjeerdsma, G.; Pinto, Y.M.; de Zeeuw, D.; van Gilst, W.H. Chronic beta-blocker treatment in patients with advanced heart failure. Effects on neurohormones. Int. J. Cardiol. 2000, 73, 7-12; discussion 13-14. [CrossRef]

139. Bodyak, N.; Ayus, J.C.; Achinger, S.; Shivalingappa, V.; Ke, Q.; Chen, Y.S.; Rigor, D.L.; Stillman, I.; Tamez, H.; Kroeger, P.E.; et al. Activated vitamin D attenuates left ventricular abnormalities induced by dietary sodium in Dahl salt-sensitive animals. Proc. Natl. Acad. Sci. USA 2007, 104, 16810-16815. [CrossRef] 
140. Schroten, N.F.; Ruifrok, W.P.; Kleijn, L.; Dokter, M.M.; Sillje, H.H.; Lambers Heerspink, H.J.; Bakker, S.J.; Kema, I.P.; van Gilst, W.H.; van Veldhuisen, D.J.; et al. Short-term vitamin D3 supplementation lowers plasma renin activity in patients with stable chronic heart failure: An open-label, blinded end point, randomized prospective trial (VitD-CHF trial). Am. Heart J. 2013, 166, 357-364.e2. [CrossRef]

141. Bellabarba, G.; Davila, D.F.; Torres, A.; Donis, J.H.; Gonzalez, J.C.; Figueroa, O.; Vasquez, C.J.; Faddoul, M.; Khoury, A. Plasma renin activity in chagasic patients with and without congestive heart failure. Int. J. Cardiol. 1994, 47, 5-11. [CrossRef]

142. Koch, J.; Pedersen, H.D.; Jensen, A.L.; Flagstad, A.; Poulsen, K. Activation of the renin-angiotensin system in dogs with asymptomatic and symptomatic dilated cardiomyopathy. Res. Vet. Sci. 1995, 59, 172-175. [CrossRef]

143. Latini, R.; Masson, S.; Anand, I.; Salio, M.; Hester, A.; Judd, D.; Barlera, S.; Maggioni, A.P.; Tognoni, G.; Cohn, J.N.; et al. The comparative prognostic value of plasma neurohormones at baseline in patients with heart failure enrolled in Val-HeFT. Eur. Heart J. 2004, 25, 292-299. [CrossRef] [PubMed]

144. Mentz, R.J.; Stevens, S.R.; DeVore, A.D.; Lala, A.; Vader, J.M.; AbouEzzeddine, O.F.; Khazanie, P.; Redfield, M.M.; Stevenson, L.W.; O'Connor, C.M.; et al. Decongestion strategies and renin-angiotensin-aldosterone system activation in acute heart failure. JACC Heart Fail. 2015, 3, 97-107. [CrossRef] [PubMed]

145. Tripathi, R.; Sullivan, R.; Fan, T.M.; Wang, D.; Sun, Y.; Reed, G.L.; Gladysheva, I.P. Enhanced heart failure, mortality and renin activation in female mice with experimental dilated cardiomyopathy. PLoS ONE 2017, 12, e0189315. [CrossRef] [PubMed]

146. Stephenson, L.A.; Kolka, M.A.; Francesconi, R.; Gonzalez, R.R. Circadian variations in plasma renin activity, catecholamines and aldosterone during exercise in women. Eur. J. Appl. Physiol. Occup. Physiol. 1989, 58, 756-764. [CrossRef]

147. Sealey, J.E. Plasma renin activity and plasma prorenin assays. Clin. Chem. 1991, 37 (10 Pt 2), 1811-1819.

148. Pitarresi, T.M.; Rubattu, S.; Heinrikson, R.; Sealey, J.E. Reversible cryoactivation of recombinant human prorenin. J. Biol. Chem. 1992, 267, 11753-11759.

149. Campbell, D.J. Critical review of prorenin and (pro)renin receptor research. Hypertension 2008, 51, $1259-1264$. [CrossRef]

150. Cartledge, S.; Lawson, N. Aldosterone and renin measurements. Ann. Clin. Biochem. 2000, 37, $262-278$. [CrossRef]

151. Campbell, D.J.; Nussberger, J.; Stowasser, M.; Danser, A.H.; Morganti, A.; Frandsen, E.; Menard, J. Activity assays and immunoassays for plasma Renin and prorenin: Information provided and precautions necessary for accurate measurement. Clin. Chem. 2009, 55, 867-877. [CrossRef] [PubMed]

152. Hartman, D.; Sagnella, G.A.; Chesters, C.A.; Macgregor, G.A. Direct renin assay and plasma renin activity assay compared. Clin. Chem. 2004, 50, 2159-2161. [CrossRef] [PubMed]

153. Tsutamoto, T.; Sakai, H.; Tanaka, T.; Fujii, M.; Yamamoto, T.; Wada, A.; Ohnishi, M.; Horie, M. Comparison of active renin concentration and plasma renin activity as a prognostic predictor in patients with heart failure. Circ. J. 2007, 71, 915-921. [CrossRef] [PubMed]

154. Wedatilake, Y.N.; Scanlon, M.J.; Barnes, S.C. The clinical utility of two renin mass methods to detect primary hyperaldosteronism compared with renin activity. Ann. Clin. Biochem. 2011, 48, 256-262. [CrossRef] [PubMed]

155. Morimoto, R.; Ono, Y.; Tezuka, Y.; Kudo, M.; Yamamoto, S.; Arai, T.; Gomez-Sanchez, C.E.; Sasano, H.; Ito, S.; Satoh, F. Rapid Screening of Primary Aldosteronism by a Novel Chemiluminescent Immunoassay. Hypertension 2017, 70, 334-341. [CrossRef] [PubMed]

156. Pavo, N.; Goliasch, G.; Wurm, R.; Novak, J.; Strunk, G.; Gyongyosi, M.; Poglitsch, M.; Saemann, M.D.; Hulsmann, M. Low- and High-renin Heart Failure Phenotypes with Clinical Implications. Clin. Chem. 2018, 64, 597-608. [CrossRef] [PubMed]

157. Wang, G.T.; Chung, C.C.; Holzman, T.F.; Krafft, G.A. A continuous fluorescence assay of renin activity. Anal. Biochem. 1993, 210, 351-359. [CrossRef]

158. Paschalidou, K.; Neumann, U.; Gerhartz, B.; Tzougraki, C. Highly sensitive intramolecularly quenched fluorogenic substrates for renin based on the combination of L-2-amino-3-(7-methoxy-4-coumaryl)propionic acid with 2,4-dinitrophenyl groups at various positions. Biochem. J. 2004, 382 (Pt 3), 1031-1038. [CrossRef] 
159. Schmiedt, C.W.; Hurley, K.A.; Tong, X.; Rakhmanova, V.A.; Po, C.L.; Hurley, D.J. Measurement of plasma renin concentration in cats by use of a fluorescence resonance energy transfer peptide substrate of renin. Am. J. Vet. Res. 2009, 70, 1315-1322. [CrossRef]

160. Schmiedt, C.W.; Nelson, S.A.; Brainard, B.M.; Brown, C.A.; Vandenplas, M.; Hurley, D.J. Bilateral renal ischemia as a model of acute kidney injury in cats. Res. Vet. Sci. 2012, 93, 950-959. [CrossRef]

161. Prysyazhna, O.; Rudyk, O.; Eaton, P. Single atom substitution in mouse protein kinase G eliminates oxidant sensing to cause hypertension. Nat. Med. 2012, 18, 286-290. [CrossRef] [PubMed]

162. Kakoki, M.; Pochynyuk, O.M.; Hathaway, C.M.; Tomita, H.; Hagaman, J.R.; Kim, H.S.; Zaika, O.L.; Mamenko, M.; Kayashima, Y.; Matsuki, K.; et al. Primary aldosteronism and impaired natriuresis in mice underexpressing TGFbeta1. Proc. Natl. Acad. Sci. USA 2013, 110, 5600-5605. [CrossRef] [PubMed]

163. Takada, S.; Kinugawa, S.; Hirabayashi, K.; Suga, T.; Yokota, T.; Takahashi, M.; Fukushima, A.; Homma, T.; Ono, T.; Sobirin, M.A.; et al. Angiotensin II receptor blocker improves the lowered exercise capacity and impaired mitochondrial function of the skeletal muscle in type 2 diabetic mice. J. Appl. Physiol. (1985) 2013, 114, 844-857. [CrossRef] [PubMed]

164. Wang, D.; Gladysheva, I.P.; Fan, T.H.; Sullivan, R.; Houng, A.K.; Reed, G.L. Atrial natriuretic peptide affects cardiac remodeling, function, heart failure, and survival in a mouse model of dilated cardiomyopathy. Hypertension 2014, 63, 514-519. [CrossRef] [PubMed]

165. Sullivan, R.D.; Mehta, R.M.; Tripathi, R.; Gladysheva, I.P.; Reed, G.L. Abstract 16743: Targeting renin activity in heart failure: precision therapy with aliskiren improves systolic function and prolongs survival in female experimental dilated cardiomyopathy. Circulation 2018, 138 (Suppl. 1).

166. Vergaro, G.; Emdin, M.; Iervasi, A.; Zyw, L.; Gabutti, A.; Poletti, R.; Mammini, C.; Giannoni, A.; Fontana, M.; Passino, C. Prognostic value of plasma renin activity in heart failure. Am. J. Cardiol. 2011, 108, 246-251. [CrossRef]

167. Poletti, R.; Vergaro, G.; Zyw, L.; Prontera, C.; Passino, C.; Emdin, M. Prognostic value of plasma renin activity in heart failure patients with chronic kidney disease. Int. J. Cardiol. 2013, 167, 711-715. [CrossRef]

168. Sim, J.J.; Shi, J.; Al-Moomen, R.; Behayaa, H.; Kalantar-Zadeh, K.; Jacobsen, S.J. Plasma renin activity and its association with ischemic heart disease, congestive heart failure, and cerebrovascular disease in a large hypertensive cohort. J. Clin. Hypertens. (Greenwich) 2014, 16, 805-813. [CrossRef]

169. Bhandari, S.K.; Batech, M.; Shi, J.; Jacobsen, S.J.; Sim, J.J. Plasma renin activity and risk of cardiovascular and mortality outcomes among individuals with elevated and nonelevated blood pressure. Kidney Res. Clin. Pract. 2016, 35, 219-228. [CrossRef]

170. Nijst, P.; Verbrugge, F.H.; Martens, P.; Bertrand, P.B.; Dupont, M.; Francis, G.S.; Tang, W.W.; Mullens, W. Plasma renin activity in patients with heart failure and reduced ejection fraction on optimal medical therapy. J. Renin Angiotensin Aldosterone Syst. 2017, 18, 1470320317729919. [CrossRef]

171. Osterziel, K.J.; Dietz, R.; Schmid, W.; Mikulaschek, K.; Manthey, J.; Kubler, W. ACE inhibition improves vagal reactivity in patients with heart failure. Am. Heart J. 1990, 120, 1120-1129. [CrossRef]

172. Borgarelli, M.; Tarducci, A.; Tidholm, A.; Haggstrom, J. Canine idiopathic dilated cardiomyopathy. Part II: Pathophysiology and therapy. Vet. J. 2001, 162, 182-195. [CrossRef] [PubMed]

173. Monnet, E.; Orton, E.C.; Salman, M.; Boon, J. Idiopathic dilated cardiomyopathy in dogs: Survival and prognostic indicators. J. Vet. Intern. Med. 1995, 9, 12-17. [CrossRef] [PubMed]

174. Tidholm, A.; Haggstrom, J.; Borgarelli, M.; Tarducci, A. Canine idiopathic dilated cardiomyopathy. Part I: Aetiology, clinical characteristics, epidemiology and pathology. Vet. J. 2001, 162, 92-107. [CrossRef] [PubMed]

175. Tidholm, A. Survival in dogs with dilated cardiomyopathy and congestive heart failure treated with digoxin, furosemide and propranolol: A retrospective study of 62 dogs. J. Vet. Cardiol. 2006, 8, 41-47. [CrossRef] [PubMed]

176. Sisson, D.D.; Thomas, W.P. Myocardial Diseases. In Textbook of Veterinary Internal Medicine, 4th ed.; Ettinger, S.J., Ed.; W. B. Saunders: Philadelphia, PA, USA, 1995; pp. 995-1005.

177. Tidholm, A.; Jonsson, L. A retrospective study of canine dilated cardiomyopathy (189 cases). J. Am. Anim. Hosp. Assoc. 1997, 33, 544-550. [CrossRef]

178. Vollmar, A.C. The prevalence of cardiomyopathy in the Irish wolfhound: A clinical study of 500 dogs. J. Am. Anim. Hosp. Assoc. 2000, 36, 125-132. [CrossRef] 
179. Tidholm, A.; Haggstrom, J.; Hansson, K. Effects of dilated cardiomyopathy on the renin-angiotensin-aldosterone system, atrial natriuretic peptide activity, and thyroid hormone concentrations in dogs. Am. J. Vet. Res. 2001, 62, 961-967. [CrossRef]

180. Tolwani, R.J.; Waggie, K.S.; Green, S.L.; Tolwani, A.J.; Lyons, D.M.; Schatzberg, A.F. Dilative cardiomyopathy leading to congestive heart failure in a male squirrel monkey (Saimiri sciureus). J. Med. Primatol. 2000, 29, 42-45. [CrossRef]

181. Shannon, R.P.; Simon, M.A.; Mathier, M.A.; Geng, Y.J.; Mankad, S.; Lackner, A.A. Dilated cardiomyopathy associated with simian AIDS in nonhuman primates. Circulation 2000, 101, 185-193. [CrossRef]

182. Sleeper, M.M.; Doane, C.J.; Langner, P.H.; Curtis, S.; Avila, K.; Lee, D.R. Successful treatment of idiopathic dilated cardiomyopathy in an adult chimpanzee (Pan troglodytes). Comp. Med. 2005, 55, 80-84. [PubMed]

183. Rajendra, R.S.; Brady, A.G.; Parks, V.L.; Massey, C.V.; Gibson, S.V.; Abee, C.R. The normal and abnormal owl monkey (Aotus sp.) heart: Looking at cardiomyopathy changes with echocardiography and electrocardiography. J. Med. Primatol. 2010, 39, 143-150. [CrossRef] [PubMed]

184. Felkai, A.; Vogelnest, L.; McNabb, S.; Allan, G.; Sangster, C. Dilated cardiomyopathy in a De Brazza's monkey (Cercopithecus neglectus). J. Med. Primatol. 2014, 43, 209-212. [CrossRef] [PubMed]

185. Houser, S.R.; Margulies, K.B.; Murphy, A.M.; Spinale, F.G.; Francis, G.S.; Prabhu, S.D.; Rockman, H.A.; Kass, D.A.; Molkentin, J.D.; Sussman, M.A.; et al. Animal models of heart failure: A scientific statement from the American Heart Association. Circ. Res. 2012, 111, 131-150. [CrossRef] [PubMed]

186. Becher, P.M.; Jugdutt, B.I.; Baugh, J.; Schmack, B. Experimental Heart Failure Models and Their Pathophysiological Characterization. Biomed. Res. Int. 2016, 2016, 2538263. [CrossRef] [PubMed]

187. Pan, L.; Gross, K.W. Transcriptional regulation of renin: An update. Hypertension 2005, 45, 3-8. [CrossRef] [PubMed]

188. Sigmund, C.D.; Gross, K.W. Structure, expression, and regulation of the murine renin genes. Hypertension 1991, 18, 446-457. [CrossRef]

189. Holm, I.; Ollo, R.; Panthier, J.J.; Rougeon, F. Evolution of aspartyl proteases by gene duplication: The mouse renin gene is organized in two homologous clusters of four exons. EMBO J. 1984, 3, 557-562. [CrossRef]

190. Hansen, P.B.; Yang, T.; Huang, Y.; Mizel, D.; Briggs, J.; Schnermann, J. Plasma renin in mice with one or two renin genes. Acta Physiol. Scand. 2004, 181, 431-437. [CrossRef]

191. Moreno, C.; Hoffman, M.; Stodola, T.J.; Didier, D.N.; Lazar, J.; Geurts, A.M.; North, P.E.; Jacob, H.J.; Greene, A.S. Creation and characterization of a renin knockout rat. Hypertension 2011, 57, 614-619. [CrossRef]

192. Clark, A.F.; Sharp, M.G.; Morley, S.D.; Fleming, S.; Peters, J.; Mullins, J.J. Renin-1 is essential for normal renal juxtaglomerular cell granulation and macula densa morphology. J. Biol. Chem. 1997, 272, 18185-18190. [CrossRef] [PubMed]

193. Sharp, M.G.; Fettes, D.; Brooker, G.; Clark, A.F.; Peters, J.; Fleming, S.; Mullins, J.J. Targeted inactivation of the Ren-2 gene in mice. Hypertension 1996, 28, 1126-1131. [CrossRef] [PubMed]

194. Ganten, D.; Wagner, J.; Zeh, K.; Bader, M.; Michel, J.B.; Paul, M.; Zimmermann, F.; Ruf, P.; Hilgenfeldt, U.; Ganten, U.; et al. Species specificity of renin kinetics in transgenic rats harboring the human renin and angiotensinogen genes. Proc. Natl. Acad. Sci. USA 1992, 89, 7806-7810. [CrossRef] [PubMed]

195. Fukamizu, A.; Sugimura, K.; Takimoto, E.; Sugiyama, F.; Seo, M.S.; Takahashi, S.; Hatae, T.; Kajiwara, N.; Yagami, K.; Murakami, K. Chimeric renin-angiotensin system demonstrates sustained increase in blood pressure of transgenic mice carrying both human renin and human angiotensinogen genes. J. Biol. Chem. 1993, 268, 11617-11621. [PubMed]

196. Merrill, D.C.; Thompson, M.W.; Carney, C.L.; Granwehr, B.P.; Schlager, G.; Robillard, J.E.; Sigmund, C.D. Chronic hypertension and altered baroreflex responses in transgenic mice containing the human renin and human angiotensinogen genes. J. Clin. Investig. 1996, 97, 1047-1055. [CrossRef] [PubMed]

197. Sugiyama, F. Development of genetically engineered mice with hypertension and hypotension. Exp. Anim. 1997, 46, 171-182. [CrossRef] [PubMed]

198. Lavoie, J.L.; Bianco, R.A.; Sakai, K.; Keen, H.L.; Ryan, M.J.; Sigmund, C.D. Transgenic mice for studies of the renin-angiotensin system in hypertension. Acta Physiol. Scand. 2004, 181, 571-577. [CrossRef] [PubMed]

199. Dickson, M.E.; Sigmund, C.D. Genetic basis of hypertension: Revisiting angiotensinogen. Hypertension 2006, 48, 14-20. [CrossRef] 
200. Spinale, F.G.; de Gasparo, M.; Whitebread, S.; Hebbar, L.; Clair, M.J.; Melton, D.M.; Krombach, R.S.; Mukherjee, R.; Iannini, J.P.; O, S.J. Modulation of the renin-angiotensin pathway through enzyme inhibition and specific receptor blockade in pacing-induced heart failure: I. Effects on left ventricular performance and neurohormonal systems. Circulation 1997, 96, 2385-2396. [CrossRef]

201. Fitzpatrick, M.A.; Rademaker, M.T.; Frampton, C.M.; Charles, C.J.; Yandle, T.G.; Espiner, E.A.; Ikram, H. Hemodynamic and hormonal effects of renin inhibition in ovine heart failure. Am. J. Physiol. 1990, 258 (6 Pt 2), H1625-H1631. [CrossRef]

202. Kanamori, T.; Wada, A.; Tsutamoto, T.; Kinoshita, M. Possible regulation of renin release by ANP in dogs with heart failure. Am. J. Physiol. 1995, 268 (6 Pt 2), H2281-H2287. [CrossRef]

203. Holycross, B.J.; Summers, B.M.; Dunn, R.B.; McCune, S.A. Plasma renin activity in heart failure-prone SHHF/Mcc-facp rats. Am. J. Physiol. 1997, 273 (1 Pt 2), H228-H233. [CrossRef]

204. Yamada, C.; Kuwahara, K.; Yamazaki, M.; Nakagawa, Y.; Nishikimi, T.; Kinoshita, H.; Kuwabara, Y.; Minami, T.; Yamada, Y.; Shibata, J.; et al. The renin-angiotensin system promotes arrhythmogenic substrates and lethal arrhythmias in mice with non-ischaemic cardiomyopathy. Cardiovasc. Res. 2016, 109, 162-173. [CrossRef] [PubMed]

205. Jones, L.R.; Suzuki, Y.J.; Wang, W.; Kobayashi, Y.M.; Ramesh, V.; Franzini-Armstrong, C.; Cleemann, L.; Morad, M. Regulation of Ca2+ signaling in transgenic mouse cardiac myocytes overexpressing calsequestrin. J. Clin. Investig. 1998, 101, 1385-1393. [CrossRef] [PubMed]

206. Cho, M.C.; Rapacciuolo, A.; Koch, W.J.; Kobayashi, Y.; Jones, L.R.; Rockman, H.A. Defective beta-adrenergic receptor signaling precedes the development of dilated cardiomyopathy in transgenic mice with calsequestrin overexpression. J. Biol. Chem. 1999, 274, 22251-22256. [CrossRef] [PubMed]

207. Hara, T.; Nishimura, S.; Yamamoto, T.; Kajimoto, Y.; Kusumoto, K.; Kanagawa, R.; Ikeda, S.; Nishimoto, T. TAK-272 (imarikiren), a novel renin inhibitor, improves cardiac remodeling and mortality in a murine heart failure model. PLoS ONE 2018, 13, e0202176. [CrossRef] [PubMed]

208. Fentzke, R.C.; Korcarz, C.E.; Lang, R.M.; Lin, H.; Leiden, J.M. Dilated cardiomyopathy in transgenic mice expressing a dominant-negative CREB transcription factor in the heart. J. Clin. Investig. 1998, 101, 2415-2426. [CrossRef]

209. Spencer, K.T.; Collins, K.; Korcarz, C.; Fentzke, R.; Lang, R.M.; Leiden, J.M. Effects of exercise training on LV performance and mortality in a murine model of dilated cardiomyopathy. Am. J. Physiol. Heart Circ. Physiol. 2000, 279, H210-H215. [CrossRef]

210. Tripathi, R.; Wang, D.; Sullivan, R.; Fan, T.H.; Gladysheva, I.P.; Reed, G.L. Depressed Corin Levels Indicate Early Systolic Dysfunction Before Increases of Atrial Natriuretic Peptide/B-Type Natriuretic Peptide and Heart Failure Development. Hypertension 2016, 67, 362-367. [CrossRef]

211. Fischer, M.; Baessler, A.; Schunkert, H. Renin angiotensin system and gender differences in the cardiovascular system. Cardiovasc. Res. 2002, 53, 672-677. [CrossRef]

212. Cunningham, M.A.; Wirth, J.R.; Scott, J.L.; Eudaly, J.; Collins, E.L.; Gilkeson, G.S. Early Ovariectomy Results in Reduced Numbers of CD11c+/CD11b+ Spleen Cells and Impacts Disease Expression in Murine Lupus. Front. Immunol. 2016, 7, 31. [CrossRef] [PubMed]

213. Gradman, A.H.; Kad, R. Renin inhibition in hypertension. J. Am. Coll. Cardiol. 2008, 51, 519-528. [CrossRef] [PubMed]

214. Corminboeuf, O.; Bezencon, O.; Remen, L.; Grisostomi, C.; Richard-Bildstein, S.; Bur, D.; Prade, L.; Strickner, P.; Hess, P.; Fischli, W.; et al. Piperidine-based renin inhibitors: Upper chain optimization. Bioorg. Med. Chem. Lett. 2010, 20, 6291-6296. [CrossRef] [PubMed]

215. Imaeda, Y.; Tokuhara, H.; Fukase, Y.; Kanagawa, R.; Kajimoto, Y.; Kusumoto, K.; Kondo, M.; Snell, G.; Behnke, C.A.; Kuroita, T. Discovery of TAK-272: A Novel, Potent, and Orally Active Renin Inhibitor. ACS Med. Chem. Lett. 2016, 7, 933-938. [CrossRef] [PubMed]

216. Wal, P.; Wal, A.; Rai, A.K.; Dixit, A. Aliskiren: An orally active renin inhibitor. J. Pharm. Bioallied. Sci. 2011, 3, 189-193. [CrossRef]

217. Seed, A.; Gardner, R.; McMurray, J.; Hillier, C.; Murdoch, D.; MacFadyen, R.; Bobillier, A.; Mann, J.; McDonagh, T. Neurohumoral effects of the new orally active renin inhibitor, aliskiren, in chronic heart failure. Eur. J. Heart Fail. 2007, 9, 1120-1127. [CrossRef] 
218. Solomon, S.D.; Shin, S.H.; Shah, A.; Skali, H.; Desai, A.; Kober, L.; Maggioni, A.P.; Rouleau, J.L.; Kelly, R.Y.; Hester, A.; et al. Effect of the direct renin inhibitor aliskiren on left ventricular remodelling following myocardial infarction with systolic dysfunction. Eur. Heart J. 2011, 32, 1227-1234. [CrossRef]

219. Schroten, N.F.; Damman, K.; Hemmelder, M.H.; Voors, A.A.; Navis, G.; Gaillard, C.A.; van Veldhuisen, D.J.; Van Gilst, W.H.; Hillege, H.L. Effect of additive renin inhibition with aliskiren on renal blood flow in patients with Chronic Heart Failure and Renal Dysfunction (Additive Renin Inhibition with Aliskiren on renal blood flow and Neurohormonal Activation in patients with Chronic Heart Failure and Renal Dysfunction). Am. Heart J. 2015, 169, 693-701.e3. [CrossRef]

220. Krum, H.; McMurray, J.J.; Abraham, W.T.; Dickstein, K.; Kober, L.; Desai, A.S.; Solomon, S.D.; Chiang, Y.; Gimpelewicz, C.; Reimund, B.; et al. The Aliskiren Trial to Minimize OutcomeS in Patients with HEart failure trial (ATMOSPHERE): Revised statistical analysis plan and baseline characteristics. Eur. J. Heart Fail. 2015, 17, 1075-1083. [CrossRef]

221. Azizi, M.; Guyene, T.T.; Chatellier, G.; Wargon, M.; Menard, J. Additive effects of losartan and enalapril on blood pressure and plasma active renin. Hypertension 1997, 29, 634-640. [CrossRef]

222. Vaduganathan, M.; Cheema, B.; Cleveland, E.; Sankar, K.; Subacius, H.; Fonarow, G.C.; Solomon, S.D.; Lewis, E.F.; Greene, S.J.; Maggioni, A.P.; et al. Plasma renin activity, response to aliskiren, and clinical outcomes in patients hospitalized for heart failure: The ASTRONAUT trial. Eur. J. Heart Fail. 2018, 20, 677-686. [CrossRef] [PubMed]

223. Luo, Y.; Chen, Q. Efficacy of aliskiren supplementation for heart failure: A meta-analysis of randomized controlled trials. Herz 2018. [CrossRef] [PubMed]

224. Gradman, A.H.; Vivas, Y. New drugs for hypertension: What do they offer? Curr. Hypertens. Rep. 2006, 8, 425-432. [CrossRef] [PubMed]

225. Oh, B.H.; Mitchell, J.; Herron, J.R.; Chung, J.; Khan, M.; Keefe, D.L. Aliskiren, an oral renin inhibitor, provides dose-dependent efficacy and sustained 24-hour blood pressure control in patients with hypertension. J. Am. Coll. Cardiol. 2007, 49, 1157-1163. [CrossRef] [PubMed]

226. Azizi, M.; Webb, R.; Nussberger, J.; Hollenberg, N.K. Renin inhibition with aliskiren: Where are we now, and where are we going? J. Hypertens. 2006, 24, 243-256. [CrossRef] [PubMed]

227. Nussberger, J.; Wuerzner, G.; Jensen, C.; Brunner, H.R. Angiotensin II suppression in humans by the orally active renin inhibitor Aliskiren (SPP100): Comparison with enalapril. Hypertension 2002, 39, E1-E8. [CrossRef] [PubMed]

228. McMurray, J.J.; Pitt, B.; Latini, R.; Maggioni, A.P.; Solomon, S.D.; Keefe, D.L.; Ford, J.; Verma, A.; Lewsey, J.; Aliskiren Observation of Heart Failure Treatment. Effects of the oral direct renin inhibitor aliskiren in patients with symptomatic heart failure. Circ. Heart Fail. 2008, 1, 17-24. [CrossRef]

229. Pitt, B.; Latini, R.; Maggioni, A.P.; Solomon, S.D.; Smith, B.A.; Wright, M.; Prescott, M.F.; McMurray, J.J. Neurohumoral effects of aliskiren in patients with symptomatic heart failure receiving a mineralocorticoid receptor antagonist: The Aliskiren Observation of Heart Failure Treatment study. Eur. J. Heart Fail. 2011, 13, 755-764. [CrossRef] [PubMed]

230. Tamargo, J.; Lopez-Sendon, J. Novel therapeutic targets for the treatment of heart failure. Nat. Rev. Drug Discov. 2011, 10, 536-555. [CrossRef]

231. Wang, W. Chronic administration of aldosterone depresses baroreceptor reflex function in the dog. Hypertension 1994, 24, 571-575. [CrossRef]

232. Barr, C.S.; Lang, C.C.; Hanson, J.; Arnott, M.; Kennedy, N.; Struthers, A.D. Effects of adding spironolactone to an angiotensin-converting enzyme inhibitor in chronic congestive heart failure secondary to coronary artery disease. Am. J. Cardiol. 1995, 76, 1259-1265. [CrossRef]

233. Upadhya, B.; Brubaker, P.H.; Morgan, T.M.; Eggebeen, J.D.; Jao, G.T.; Stewart, K.P.; Kitzman, D.W. The effect of Aliskiren on exercise capacity in older patients with heart failure and preserved ejection fraction: A randomized, placebo-controlled, double-blind trial. Am. Heart J. 2018, 201, 164-167. [CrossRef] [PubMed]

234. Ziaeian, B.; Fonarow, G.C. Epidemiology and aetiology of heart failure. Nat. Rev. Cardiol. 2016, 13, 368-378. [CrossRef] [PubMed]

235. Metra, M.; Teerlink, J.R. Heart failure. Lancet 2017, 390, 1981-1995. [CrossRef]

236. Fedele, F.; Mancone, M.; Adamo, F.; Severino, P. Heart Failure With Preserved, Mid-Range, and Reduced Ejection Fraction: The Misleading Definition of the New Guidelines. Cardiol. Rev. 2017, 25, 4-5. [CrossRef] 
237. Seferovic, P.M.; Polovina, M.; Bauersachs, J.; Arad, M.; Gal, T.B.; Lund, L.H.; Felix, S.B.; Arbustini, E.; Caforio, A.L.P.; Farmakis, D.; et al. Heart failure in cardiomyopathies: A position paper from the Heart Failure Association of the European Society of Cardiology. Eur. J. Heart Fail. 2019, 21, 553-576. [CrossRef] [PubMed]

238. Connelly, K.A.; Advani, A.; Advani, S.; Zhang, Y.; Thai, K.; Thomas, S.; Krum, H.; Kelly, D.J.; Gilbert, R.E. Combination angiotensin converting enzyme and direct renin inhibition in heart failure following experimental myocardial infarction. Cardiovasc. Ther. 2013, 31, 84-91. [CrossRef]

239. Thomas, C.M.; Yong, Q.C.; Seqqat, R.; Chandel, N.; Feldman, D.L.; Baker, K.M.; Kumar, R. Direct renin inhibition prevents cardiac dysfunction in a diabetic mouse model: Comparison with an angiotensin receptor antagonist and angiotensin-converting enzyme inhibitor. Clin. Sci. (Lond.) 2013, 124, 529-541. [CrossRef]

240. Westermann, D.; Riad, A.; Lettau, O.; Roks, A.; Savvatis, K.; Becher, P.M.; Escher, F.; Jan Danser, A.H.; Schultheiss, H.P.; Tschope, C. Renin inhibition improves cardiac function and remodeling after myocardial infarction independent of blood pressure. Hypertension 2008, 52, 1068-1075. [CrossRef]

241. Rashikh, A.; Ahmad, S.J.; Pillai, K.K.; Kohli, K.; Najmi, A.K. Aliskiren attenuates myocardial apoptosis and oxidative stress in chronic murine model of cardiomyopathy. Biomed. Pharm. 2012, 66, 138-143. [CrossRef]

242. Moniwa, N.; Varagic, J.; Ahmad, S.; VonCannon, J.L.; Simington, S.W.; Wang, H.; Groban, L.; Brosnihan, K.B.; Nagata, S.; Kato, J.; et al. Hemodynamic and hormonal changes to dual renin-angiotensin system inhibition in experimental hypertension. Hypertension 2013, 61, 417-424. [CrossRef] [PubMed]

243. Ding, W.; Li, X.; Wu, W.; He, H.; Li, Y.; Gao, L.; Gan, L.; Wang, M.; Ou, S.; Liu, J. [Aliskiren inhibits angiotensin II/angiotensin 1-7(Ang II/Ang1-7) signal pathway in rats with diabetic nephropathy]. Xi Bao Yu Fen Zi Mian Yi Xue Za Zhi 2018, 34, 891-895. [PubMed]

244. Antlanger, M.; Bernhofer, S.; Kovarik, J.J.; Kopecky, C.; Kaltenecker, C.C.; Domenig, O.; Poglitsch, M.; Saemann, M.D. Effects of direct renin inhibition versus angiotensin II receptor blockade on angiotensin profiles in non-diabetic chronic kidney disease. Ann. Med. 2017, 49, 525-533. [CrossRef] [PubMed]

245. Campbell, D.J.; Zhang, Y.; Kelly, D.J.; Gilbert, R.E.; McCarthy, D.J.; Shi, W.; Smyth, G.K. Aliskiren increases bradykinin and tissue kallikrein mRNA levels in the heart. Clin. Exp. Pharm. Physiol. 2011, 38, 623-631. [CrossRef] [PubMed]

246. Koid, S.S.; Ziogas, J.; Campbell, D.J. Aliskiren reduces myocardial ischemia-reperfusion injury by a bradykinin B2 receptor- and angiotensin AT2 receptor-mediated mechanism. Hypertension 2014, 63, 768-773. [CrossRef] [PubMed]

247. Furukawa, M.; Gohda, T.; Hagiwara, S.; Tanimoto, M.; Horikoshi, S.; Funabiki, K.; Tomino, Y. Effect of the Direct Renin Inhibitor Aliskiren on Urinary Albumin Excretion in Spontaneous Type 2 Diabetic KK-A (y) Mouse. Int. J. Nephrol. 2013, 2013, 519130. [CrossRef] [PubMed]

248. Poss, J.; Werner, C.; Lorenz, D.; Gensch, C.; Bohm, M.; Laufs, U. The renin inhibitor aliskiren upregulates pro-angiogenic cells and reduces atherogenesis in mice. Basic Res. Cardiol. 2010, 105, 725-735. [CrossRef] [PubMed]

249. Seto, S.W.; Krishna, S.M.; Moran, C.S.; Liu, D.; Golledge, J. Aliskiren limits abdominal aortic aneurysm, ventricular hypertrophy and atherosclerosis in an apolipoprotein-E-deficient mouse model. Clin. Sci. (Lond.) 2014, 127, 123-134. [CrossRef] [PubMed]

(C) 2019 by the authors. Licensee MDPI, Basel, Switzerland. This article is an open access article distributed under the terms and conditions of the Creative Commons Attribution (CC BY) license (http://creativecommons.org/licenses/by/4.0/). 